
patterns in Spain: some implications for financial exclusion Luisa Alamá and Emili Tortosa-Ausina 
Los documentos de trabajo del Ivie ofrecen un avance de los resultados de las investigaciones económicas en curso, con objeto de generar un proceso de discusión previo a su remisión a las revistas científicas. Al publicar este documento de trabajo, el Ivie no asume responsabilidad sobre su contenido.

Ivie working papers offer in advance the results of economic research under way in order to encourage a discussion process before sending them to scientific journals for their final publication. Ivie's decision to publish this working paper does not imply any responsibility for its content.

La Serie EC, coordinada por Matilde Mas, está orientada a la aplicación de distintos instrumentos de análisis al estudio de problemas económicos concretos.

Coordinated by Matilde Mas, the EC Series mainly includes applications of different analytical tools to the study of specific economic problems.

Todos los documentos de trabajo están disponibles de forma gratuita en la web del Ivie http://www.ivie.es, así como las instrucciones para los autores que desean publicar en nuestras series.

Working papers can be downloaded free of charge from the Ivie website http://www.ivie.es, as well as the instructions for authors who are interested in publishing in our series.

Edita / Published by: Instituto Valenciano de Investigaciones Económicas, S.A.

Depósito Legal / Legal Deposit no.: V-3642-2011

Impreso en España (octubre 2011) / Printed in Spain (October 2011) 


\title{
Bank branch geographic location patterns in Spain: some implications for financial exclusion*
}

\author{
Luisa Alamá and Emili Tortosa-Ausina**
}

\begin{abstract}
Over the last twenty years, the Spanish banking industry has been deeply reshaped in several respects. One of the features that has allowed this has been the geographic expansion of most savings banks, which have been expanding into other regions (different from their regions of origin) at a significant pace since 1989. Almost simultaneously, the Spanish economy has grown at remarkable annual rates, a growth pattern which came to an abrupt halt in 2008. Under these circumstances, this paper analyzes the geographic expansion patterns of Spanish financial institutions during the post-deregulation period. This goal extends previous analyses in two main ways, considering a broader set of variables affecting bank branch location, and using a quantile regression in order to obtain results which go beyond conditional mean models. Results indicate: (i) location and geographic diversification patterns vary mostly across firms and by type of firm; (ii) the evaluation of growth and financial development at municipal level indicates that some communities have experienced financial exclusion; (iii) it is difficult to establish a linear relationship to explain bank branch geographic diversification strategies.
\end{abstract}

Keywords: bank branch, financial exclusion, geographic expansion, service accessibility.

JEL Classification: D40, L11, G21, C25.

\section{Resumen}

Durante los últimos 20 años la industria bancaria española ha sido reestructurada en varias facetas. Uno de las características que más ha contribuido a dicho cambio ha sido la expansión geográfica de las cajas de ahorros, que han ido penetrando en otros mercados (diferentes a lo que podríamos denominar sus "mercados naturales") a ritmos elevados desde 1989. Prácticamente a la vez, la economía española ha venido creciendo a tasas también elevadas, un patrón que se detuvo abruptamente en 2008. En estas circunstancias, el presente trabajo analiza los patrones de expansión geográfica de las instituciones financieras españolas en la época de la desregulación. Este objetivo extiende análisis previos en dos direcciones, al considerar un conjunto de variables más amplio que pueden afectar a la localización de oficinas bancarias, y al utilizar regresión cuantil de cara a obtener resultados que pueden ir más allá de lo que aportan los modelos que resumen los resultados en efectos promedio. Los resultados indican que: (i) los patrones de localización y diversificación geográfica varían entre empresas pero también entre tipos de empresas; (ii) la evaluación del crecimiento y el desarrollo financiero a nivel municipal indica que algunas comunidades pueden haber experimentado exclusión financiera; (iii) es difícil establecer una relación lineal que explique las estrategias de diversificación geográfica.

Palabras clave: oficina bancaria, exclusión financiera, expansión geográfica, acceso a servicios financieros.

\footnotetext{
"We thank participants at the $50^{\text {th }}$ European Regional Science Association Congress held in Jönköping (Sweden, August 2010) for helpful comments. Emili Tortosa-Ausina acknowledges the financial support of Fundació Caixa CastellóBancaixa (P1.1B2008-46), the Spanish Ministry of Science and Education (ECO2008-03813/ECON and ECO2008-05908C02-01/ECON) and the Valencian Regional Government (PROMETEO/2009/066). We also thank the comments by three anonymous referees and the editor, Dan Rickman, for helpful comments. The usual disclaimer applies.

** L. Alamá: Universitat Jaume I and Institut Inter-universitari de Desenvolupament Local (IIDL). E. Tortosa-Ausina: Universitat Jaume I and Instituto Valenciano de Investigaciones Económicas (Ivie). Correspondence to E. TortosaAusina, e-mail: tortosa@uji.es.
} 


\section{Introduction}

Over the last few years, one of the phenomena which has contributed most to the reshaping of the Spanish banking industry has been the geographic expansion policies adopted by many financial institutions in general, and savings banks in particular. These initiatives already have a long history, and began strongly after the passing of the corresponding law in $1988,{ }^{1}$ which allowed savings banks to expand nationwide. Twenty years later, the structure of the Spanish banking industry appears very different, with savings banks' shares of total industry assets quite close to those of commercial banks. The new territorial expansion policies adopted by many savings banks, which have entered markets different to those in which they had been operating before the passing of the 1988 act on branches, has been largely responsible for this new structure.

However, the current economic and financial crisis, which is particularly affecting many savings banks, largely because of their important role in financing the construction boom of the last few years, could be calling their geographic expansion and diversification policies into question. Nevertheless, the heterogeneity of geographic expansion decisions across financial institutions has been remarkable. Yet it is difficult to evaluate the impact of the expansion policies with precision unless we can evaluate what the expansion and location patterns have been when choosing the locations for new branches. Before the post-deregulation scenario emerged, Jack Revell (1989) predicted that a model in which savings banks competed against one other would not be appropriate for the Spanish banking sector. He considered two major issues that savings banks were facing in both Spain and the rest of Europe: how to raise additional capital to meet stricter capital adequacy regulations and finance geographic expansion, and how to meet increased competition. After examining the optimum structure of a savings bank system in light of economies of scale and scope, analyzing the savings bank mergers that took place in the 1990s, and discussing the functions of central savings banks and regional federations, he presented a general model of the structure of the savings bank movement that could best meet the increased competition. This model was not adopted by Spanish savings banks.

The literature that has been paying attention to aspects related to expansion and geographic diversification patterns of banking firms, despite fact that the importance of the phenomenon is still relatively limited, even though the variety of points of view offered is a broad one. This is partly related to the fact that the number of countries in which this type of experience has

\footnotetext{
${ }^{1}$ Real Decreto $1582 / 1988$.
} 
taken place is limited, to the point that we will only find a parallel with the Spanish case in the U.S., where the passing of the Riegle-Neal Act in 1984 allowed banks to branch into states other than the state of origin of each bank. Given the importance of both the phenomenon and the U.S. banking industry itself, the literature analyzing different aspects related to the effects of the Riegle-Neal Act has been expanding at a moderate pace. ${ }^{2}$

In the Spanish case, despite the importance of the phenomenon and the impact that it might have had both on the real economy and also on the financial institutions themselves, especially those which expanded geographically (and also on those which did not expand), the literature is still relatively scarce. Some studies have analyzed aspects related to entry and geographic diversification decisions (Fuentelsaz and Gómez, 2001; Fuentelsaz et al., 2002), the multimarket contact and strategic similarity in the context of entry decisions (Fuentelsaz and Gómez, 2006), or how the geographic expansion decisions may be related to the phenomenon of financial exclusion (Bernad et al., 2008). This last line of research is related to some pernicious effects of deregulation, which might have encouraged some firms to abandon areas with relatively low per capita income levels. The studies by De Juan $(2003,2008)$ are more focused on applying industrial economics models of branching to the case of the Spanish banking system. In De Juan (2003) the predictions of Sutton's (1997) independent submarkets model are tested for the case of the Spanish retail banking market, whereas in De Juan (2008) the entry threshold concept developed by Bresnahan et al. (1987) is used to examine how competitive conditions varied in Spanish local banking markets in 2003.

Although the studies reviewed in the above paragraph have achieved relevant results, which have contributed to an overall improvement in the knowledge of geographic diversification and entry in local banking markets, none of them has dealt explicitly with the question of what the geographic or spatial determinants of bank branches are. However, understanding the factors underlying the branch location decisions of banks is itself of policy interest, especially in the current scenario of financial crisis. As indicated by Chang et al. (1997), bank branches tend to be unevenly distributed, an unevenness which is important to understand because bricks-and-mortar branch presence has traditionally been relevant for bank service accessibility. The aim of this paper is therefore to elucidate the determinants and variables that influence bank branch location in Spain. Such an analysis may help develop further insights on relevant topics such as access to finance. As indicated by Okeahalam (2009), it would seem that, a priori, branch location may be influenced by socioeconomic variables and, in such a case,

\footnotetext{
${ }^{2}$ A brief review can be found in Illueca et al. (2009).
} 
the extent of this influence may not be known, but it should, at least, be predictable. Given the rapid increase in the level of branching activity up to the end of the 2000s, and the potential for forthcoming de-branching derived from the restructuring process in the Spanish savings banks sector, it is important that the impact of branching be thoroughly understood.

The only previous contribution in which related questions are approached in the Spanish context is that by Bernad et al. (2008), who analyze the long-term consequences of deregulation on financial inclusion in the Spanish banking industry. Our study extends their methods and findings, by considering a more recent period, a much more comprehensive set of variables, and also a more flexible technique (quantile regression; see Koenker, 2001), which enables them to perform a much more accurate analysis of financial exclusion. By estimating conditional quantile functions, it is possible to perform a more complete analysis of the stochastic relationship between economic variables than that provided by classical linear regression, which generally confines the analysis to estimation and inference about conditional mean functions.

The paper by Bernad et al. (2008) provides a review of the long-run effects on the availability of banking services in low-income communities. As indicated by these authors and others (Leyshon and Thrift, 1996), this topic has been widely studied in the US, but much less work has been done in other countries. Therefore, it is relevant per se to analyze the topic in other contexts since, as indicated by the literature on the expansion method (Casetti, 1991; Jones and Bullen, 1994), results might depend upon context. In addition, the topic gains relevance in those countries whose banking systems are going through deep restructuring, which corresponds to the particular case of Spain. Given the recent increase in the level of branching activity, and the potential for forthcoming branching legislation at the national level, it is important that the impact of branching be thoroughly understood. These statement corresponds to the U.S. banking industry (Evanoff, 1988), but holds easily in the case of the Spanish banking industry.

Not only Leyshon and Thrift (1996) but also others such as Marshall (2004) and Pollard (1996) have pointed out that (bank) deregulation and its associated phenomena (mergers, entry, and exit) could have affected perversely the availability of banking services to certain social groups, or to some specific geographic areas, following multiple paths. In our particular case, despite deregulation is usually positive to foster competition, it might jeopardize the presence of bank offices in less attractive markets, with lower levels of demand or relative income. Under these circumstances, if we consider the existence of bank branches in a particular location as a reasonable indicator of the availability of bank services, the effect not only of deregulation 
but also of a more general restructuring in the industry - such as that which is taking place in the Spanish banking sector-could have a potential negative effect on the level of service and commitment to some geographic areas (Bierman et al., 1995; Leyshon and Thrift, 1995).

The literature analyzing the effect of deregulation on the availability of banking services to less-favored communities, apart from being geographically biased, with the vast majority of studies focusing on the US case, is also mixed in terms of results. In addition, the number of studies is relatively low, and were published a while ago. The related contributions would include Seaver and Fraser (1979), Pollard (1996), Bierman et al. (1995), Lanzillotti and Saving (1969), Gunther (1997), or Evanoff (1988), among others. ${ }^{3}$ Some of them will be reviewed more carefully throughout the article, especially in the sections devoted to analyze the likely determinants of bank branch expansion. However, as indicated by Evanoff (1988), we should bear in mind that the existing studies on this field are "somewhat limited, dated, and have generated mixed results" and, therefore, "they are of limited value from a current public policy perspective" (p.192 Evanoff, 1988).

Most of the ideas presented in the preceding paragraphs deal with financial exclusion issues. Apart from those papers handling the topic directly (Leyshon and Thrift, 1995, 1996), there are some other contributions dealing with the issue from a point of view of European banking (Carbó et al., 2005, 2007). These authors have been dealing with the topic carefully. Their definition of financial exclusion is based on Sinclair (2001), who describes it as "the inability to access necessary financial services in an appropriate form. Exclusion can come about as a result of problems with access, conditions, prices, marketing or self-exclusion in response to negative experiences or perceptions". In one of their contributions, Carbó et al. (2007) indicate that financial exclusion had become more visible over the past decade. Although our methods will not allow direct testing for financial exclusion, they are strongly linked to this question, which has regained importance in the current scenario of economic and financial crisis, where access to credit is becoming more difficult for some communities.

The paper proceeds as follows. Section 2 presents some descriptive data on the branching patterns of Spanish banking institutions, including a subsection presenting some information on the changing geography of Spanish bank branching. Section 3 presents the data and performs the regression analysis using both ordinary least squares (OLS) and regression quantiles.

\footnotetext{
${ }^{3}$ Other relevant studies on the topic would include Calem and Nakamura (1988) and Damar (2007). The former analyzes, theoretically and empirically, the extent to which the forming of differential branch networks extends the boundaries of competitive interaction. The latter is deals with the bank consolidation process and the number of bank branches in the aftermath of the banking crisis in Turkey.
} 
Finally, section 4 presents some conclusions.

\section{Deregulation and the changing geography of the Spanish banking}

\subsection{A reshaped banking industry}

As indicated in Figure 1, if we consider the evolution of the three types of banking institutions in the Spanish banking sector together, i.e., commercial banks, savings banks and credit unions, it is observed that the branching tendencies differ strongly, and are expected to differ even more in the future. Overall, the total number of branches has increased steadily, from 31,972 by 1988 to 42,894 by 2010, which represents an average annual increase of $1.34 \%$. The peak had been reached earlier (in 2008 the total number of branches was 45,662), but the deep international economic and financial crisis has impelled many firms, especially savings banks, to redefine their expansion strategies. This tendency is very much expected to hold in the near future, not only because of the crisis itself but also due to the effects of the passing of the Royal Decree-Law 9/2009 of 26 June 2009, which laid the legal foundations in Spain for the restructuring of the savings bank sector.

A closer look to Figure 1 reveals that, for some years, the increase in the total number of branches has been impressive. For instance, between 2005 and 2007 the number of branches increased by $8.38 \%$, which represents almost 4,000 more branches. By contrast, in some years the total number of branches declined moderately, for instance, between 1992 and 1993, due to both the economic crisis and the mergers and acquisitions' process that was affecting savings banks, as well as in the years of the dot-com crisis.

Table 1 provides summary statistics on the market shares of commercial banks, savings banks, and credit unions, for both loans (and credits) and deposits, including both the private and public sectors. We can distinguish a sharp change of tendencies after 2008, generally to the detriment of savings banks. In contrast, this was the group of banks whose growth rates increased more rapidly since 1988. For instance, as reported in Table 2, between 1998 and 2008 the volume of loans and credits issued by savings banks increased annually by at a remarkable $16.25 \%$-although the increase was also noteworthy for commercial banks (12.60\%) and, more importantly, credit unions (15.90\%). In contrast, the volume of deposits raised by each type of banking firms during the same period (1998-2008) increased at more moderate (and similar) rates, approximately $10 \%$.

The discrepancy observed between the deposits raised and loans issued for savings banks 
Figure 1: Evolution of bank branches per type of banking firm, 1988-2010

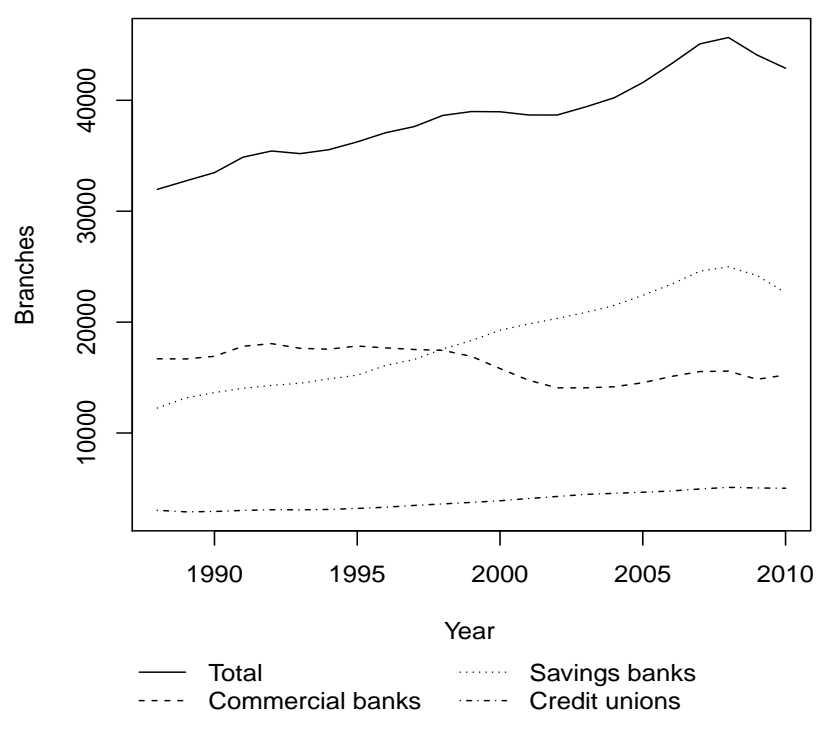

(a) Total

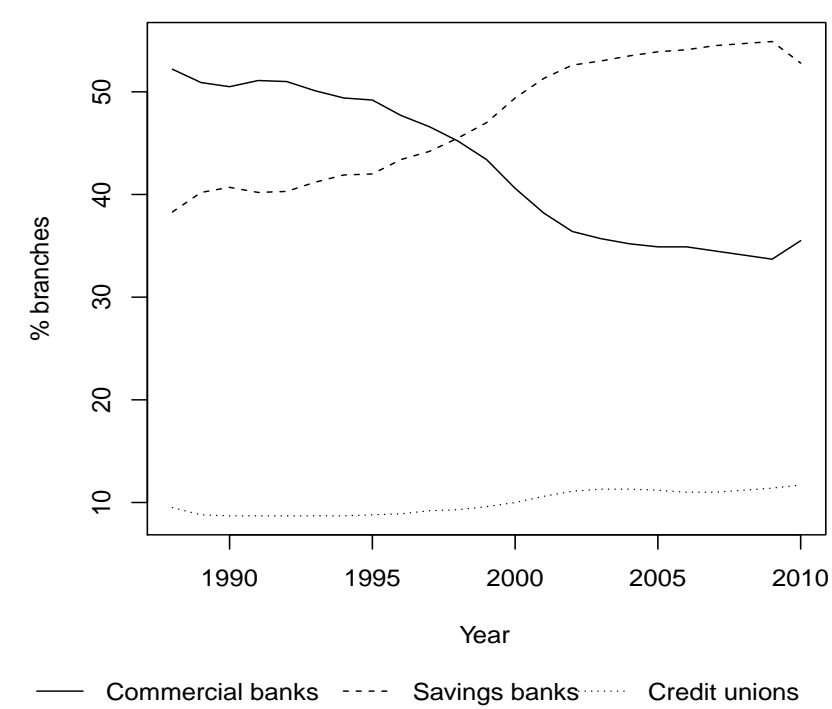

(b) Shares 
Table 1: Shares of the different bank types in the Spanish banking sector, 1988-2010

\begin{tabular}{|l|rrrr|rrrr|}
\hline & \multicolumn{3}{|c|}{ Loans and credits } & \multicolumn{4}{c|}{ Deposits } \\
\cline { 2 - 9 } & 1988 & 1998 & 2008 & 2010 & 1988 & 1998 & 2008 & 2010 \\
\hline Commercial banks & 63.72 & 54.27 & 45.60 & 47.62 & 53.66 & 43.93 & 43.61 & 46.13 \\
Savings banks & 33.33 & 41.20 & 49.17 & 47.08 & 42.14 & 50.19 & 50.16 & 47.23 \\
Credit unions & 2.96 & 4.53 & 5.23 & 5.30 & 4.21 & 5.88 & 6.23 & 6.64 \\
\hline
\end{tabular}

Source: Bank of Spain. 
would indicate that their geographic expansion policies have been successful in terms of loans issued, but less so in terms of deposits raised. This would be further corroborated taking into account that the number of branches actually decreased for commercial banks since the late 1990s. In the case of credit unions, the tendencies observed are similar to those found for savings banks, although their geographic expansion policies were much more conservative.

If we extend the analysis to the crisis' years (2008-2010), as reported in Table 2, we also observed different patterns for the different types of firms. Although both commercial banks and credit unions have been able to grow in terms of loans, credits and deposits (at least in nominal terms), the views are much more different for savings banks, whose volume of loans issued and deposits raised actually fell between 2008 and 2010.

Taking into account the total number of branches for any of the three aggregates (commercial banks, savings banks or credit unions), it is apparent that lifting the restrictions on branching for the institutions that could not do it—savings banks and credit unions-has resulted in these types of firms following very different strategies to those of commercial banks. Indeed, the evolution of the aggregate (solid line in subfigure 1a) is the result of very disparate trends for the different types of firms. In the case of savings banks (dotted line in subfigure 1a) the number of branches has increased from 12,252 by 1988 to 22,649 by 2010 , which represents an average increase of $2.62 \%$ per year. The increase would be even higher if we compare 1988 to 2008 (in this case the increase would be 3.43\%!) This has also led this type of firm to increase its share of branches, as indicated in subfigure $1 \mathrm{~b}$ (from $38.32 \%$ to $52.80 \%$ between 1988 and 2010 although, again, the peak of 54.90\% had been reached by 2009). In the case of the credit unions, the rise has also been quite remarkable-from 3,029 to 5,018 branches, representing a $2.66 \%$ annual increase. However, the relative importance of this type of institution is minor, as its share of branches is still limited (11.70\% in 2010).

The trends for commercial banks have been in the opposite direction. As shown in subfigure 1a, the number of branches has actually decreased from 16,691 to 15,227 between 1988 and 2010, representing a $0.43 \%$ annual decline. Most of the decline occurred in the first half of the sample period (between 1988 and 2001), which is the period when savings banks expanded more aggressively. By contrast, in the second half of the period, the total number of branches actually increased slightly, although the rise would have been higher had we excluded years 2009 and 2010. Therefore, although commercial banks and savings banks face the same regulatory system (the remaining differences are almost entirely restricted to their type of ownership), the opposing branching strategies could suggest that differences are stronger 
Table 2: Annual growth rates (loans, credits and deposits) of the different bank types in the Spanish banking sector, 1988-2010 (\%)

\begin{tabular}{|l|rrr|rrr|}
\hline & \multicolumn{3}{|c|}{ Loans and credits } & \multicolumn{3}{c|}{ Deposits } \\
\cline { 2 - 7 } & $1988-1998$ & $1998-2008$ & 2008-2010 & $1988-1998$ & $1998-2008$ & 2008-2010 \\
\hline Commercial banks & 1.0865 & 1.1260 & 1.0172 & 1.0586 & 1.1006 & 1.0202 \\
Savings banks & 1.1239 & 1.1625 & 0.9881 & 1.0953 & 1.1013 & 0.9815 \\
Credit unions & 1.1461 & 1.1590 & 1.0065 & 1.1113 & 1.1071 & 1.0227 \\
\hline
\end{tabular}

Source: Bank of Spain. 
than might a priori be expected.

Therefore, according to the information reported in figure 1, the expansion strategies for all commercial banks, savings banks and credit unions have differed sharply, especially when comparing commercial banks with the other two groups of firms. However, there might also have been differences within groups of firms. As indicated by Illueca et al. (2009), the rise in the total number of savings bank branches between 1992 and 2004 was basically related to expansion in other markets. However, it could also be corroborated that there were other strategies, as the number of branches belonging to savings banks in their natural markets also increased sharply. Following Illueca et al. (2009), these strategies could be defined as offensive (or aggressive) strategies and defensive strategies. They are clearly different, not only in their implementation but also in their objectives. Defensive strategies would be adopted by companies trying to strengthen their market share in their traditional markets. Offensive strategies are chosen by banks attempting to increase their presence in a market in which they could not operate before 1989. This is especially the case for savings banks. These patterns show multiple variations, as several firms adopted mixed strategies. For instance, some large savings banks strengthened both its position in their natural market-in order to fend off potential entrants-and in other markets, where they expanded strongly.

The branching strategies of the different types of financial intermediaries in Spain might also have affected the bank market structure. The studies by Fuentelsaz and Gómez (Fuentelsaz and Gómez, 1998, 2001, 2006) point out in this direction. As indicated in Table 1, over the 19882008 period, the market shares of the three types of banking firms changed in their relative positions. This trend holds for both sides of the balance sheet-credits and deposits. Whereas savings banks had always been able to raise deposits using the traditional way, i.e. by setting new branches, 2008 we can observe how the number of savings banks' branches has increased more than proportionally compared to the volume of their total deposits.

The literature on deregulation and the geographic expansion of financial institutions has also been investigating their implications for economic growth. This is a particular case of the broader literature on the finance-growth nexus (see, for instance, the recent contributions by Demirgüç-Kunt, 2010; Demirgüç-Kunt and Servén, 2010). This topic has been investigated in the U.S., as documented by Jayaratne and Strahan (1996), Krol and Svorny (1996), Kroszner and Strahan (1999) or Freeman (2002), among others. For other countries, the empirical evidence available is much scarcer. In the particular case of Spain that we are dealing with the issue has been studied by Carbó et al. (2003) who study five large regions in Spain over 1986-98 and, 
using different indicators of market competition, they analyse changes in regional competition and growth. Granger-causality tests, showing that differences in competition are not associated with improved regional growth. More recently, Carbó-Valverde et al. (2007) have employed dynamic causality and panel data techniques on a sample of Spanish banks during 1993-1999, finding that at a regional level, economic growth predicted financial deepening in this period.

The tendencies observed for the most recent years of the sample (between 2008 and 2010), which correspond to the crisis' years, suggest that there could be some implications for financial exclusion. The number of savings banks' branches is decreasing steadily, and it is expected to decrease further due to the consolidation of the savings banks' sector. This consolidation process has accelerated after the passing of the Royal Decree-Law 9/2009, also known as FROB Law, ${ }^{4}$ which was unavoidable in the unfavorable economic and financial environment that has brought to light the negative consequences of some imbalances in the sector such as the concentration in the real estate development and construction sector, the dependence on wholesale market funding, excess capacity, small average size of institutions, loss of profitability, etc.

The glooming prospects for financial exclusion are related to the fact that, as indicated by Carbó et al. $(2005,2007)$, in Spain savings banks (especially through its foundations) pursue objectives aimed at helping to reduce financial exclusion. Previously to the economic and financial crisis, for several years not only the Confederation of Spanish savings banks but savings banks themselves had publicly stated that an important objective for them was to reduce financial exclusion, offering banking products specifically designed for vulnerable groups. These initiatives had led some authors to conclude that "Spain is probably among the leading countries in tackling financial exclusion via 'private market' means" (p.107 Carbó et al., 2005). The intense process of savings banks' mergers and integrations set in train by the FROB, which is radically altering the landscape of the sector, might thwart the previous commitment of savings banks to fend financial exclusion.

There are two other milestones in the savings banks' restructuring process. First, the Royal Decree-Law 11/2010 (9 July 2010), known as Savings Bank Law, has permitted savings banks to opt to pursue their activity through a commercial bank and, consequently, enabled them to tap capital markets in order to strengthen their capital and improve their governance. Second, the Royal Decree-Law 2/2011 (26 March 2011) on recapitalization initiated the last stage of the process of savings banks' restructuring by strengthening the Spanish financial system. ${ }^{5}$

\footnotetext{
${ }^{4}$ In Spanish, Fondo de Reestructuración Ordenada Bancaria, which can be translated as the Fund for the Orderly Restructuring of the Banking Sector.

${ }^{5}$ This objective would be achieved by setting a new capital ratio of either $8 \%$ or $10 \%$ to be met with core capital
} 
In practical terms, the restructuring process will imply a change of corporate model, with the conversion of nearly all savings banks into commercial banks, with the ultimate aim of improving their governance and recapitalization. The consequences will be more ample, including also balance sheet write-downs, a sharp consolidation process (from 45 to 15 institutions), reduction in capacity (between $10 \%$ and $25 \%$ of offices are expected to close, and between $12 \%$ and $18 \%$ in staff will be reduced), new corporate model, improved governance, increase in solvency requirements, and recapitalization. Although the aims pursued are reasonable, this process could have negative consequences in terms of financial exclusion, especially because of the consolidation process, reduction in capacity, and perhaps the new corporate model—with more professional management.

However, the emerging scenarios could be different. For instance, Damar (2007), in his study on the restructuring plan that followed the banking crisis experienced by Turkey and how it affected branching patterns, found that, "contrary to popular belief, mergers between healthy institutions do not always cause a decrease in the number of branches; rather, they are shown to increase the availability of banking services in concentrated markets" (p.2886 Damar, 2007).

\subsection{The changing geography of the Spanish banking industry}

The maps contained in Figures 2 and 3 report graphical information on the geographic expansion of Spanish banking firms. Specifically, they contain information at provincial level (NUTS level 3 according to European Union notation) about the distribution of branches in Spain, not only in absolute terms (Figure 2) but also compared to the mean (Figure 3). In these figures we compare 1992 with 2008. We have selected 1992 as the base year because, before that, many savings banks were involved in costly mergers, preventing them from expanding geographically until the processes were complete.

Figures $2 \mathrm{a}$ and $2 \mathrm{~b}$ corroborate the aggregate results found for commercial banks shown in Figure 1-i.e., overall, the number of commercial bank branches has decreased. However, the geographic distribution shows that the trends have differed for the different provinces, as in some of them the number of branches owned by commercial banks has fallen more sharply than in others. The only cases where the number of commercial bank branches has actually risen between 1992 and 2008 are Madrid, Álava, Almería, Málaga, Las Palmas and Tenerife. In some of these cases the increase was virtually negligible (Álava and Tenerife), but in others it

instruments and provided for financial support by the FROB. 
Figure 2: Branches per province (NUTS level 3), Spanish banking sector, 1992 vs. 2008

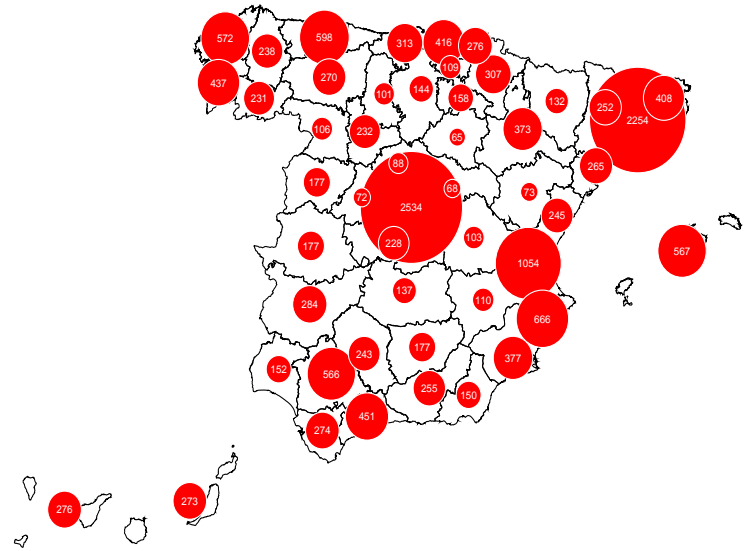

(a) Commercial banks, 1992

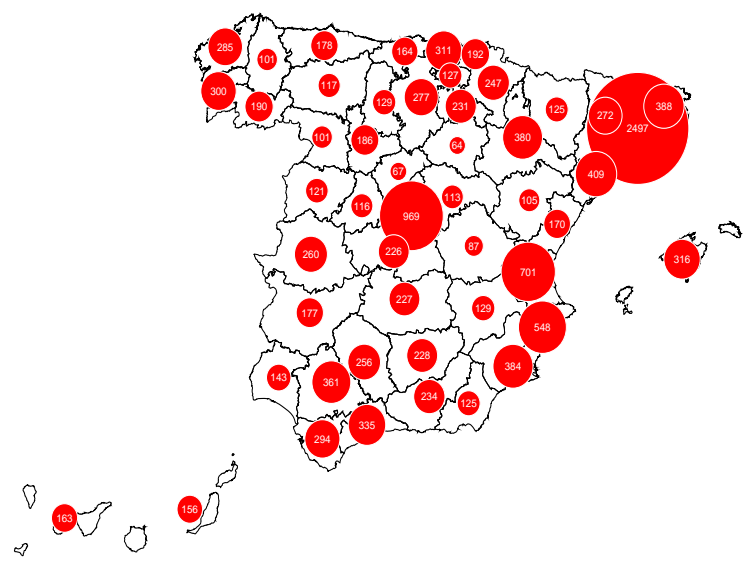

(c) Savings banks, 1992

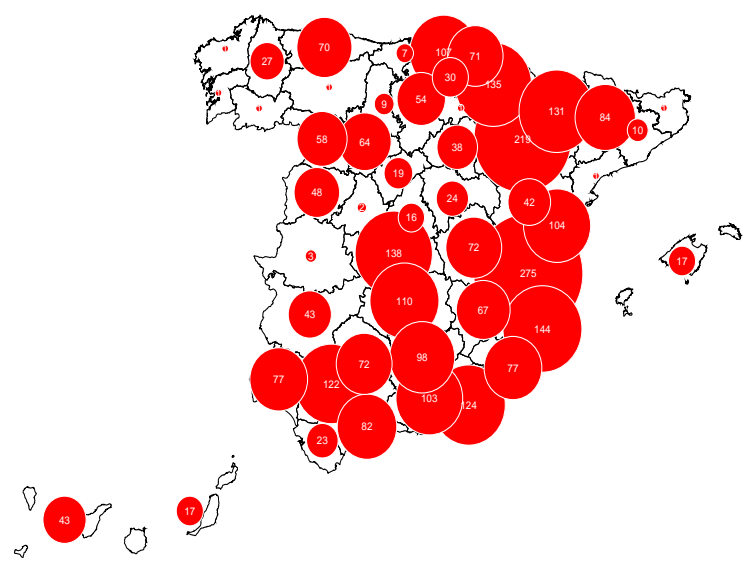

(e) Credit unions, 1992

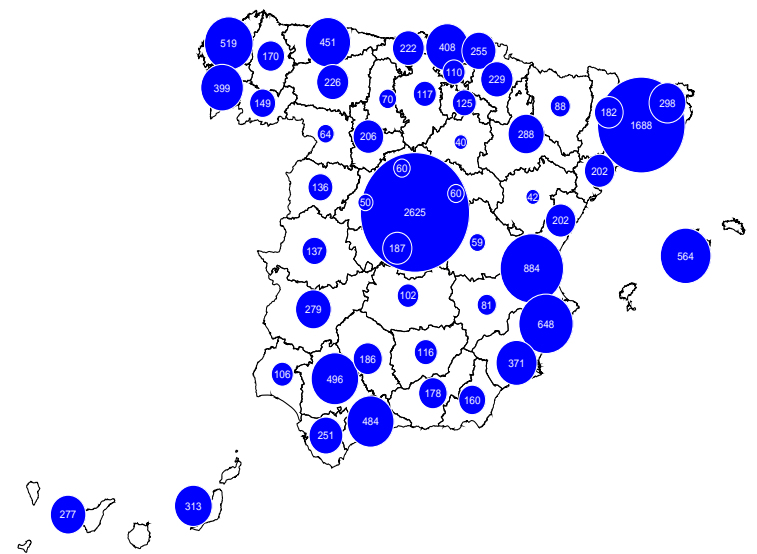

(b) Commercial banks, 2008

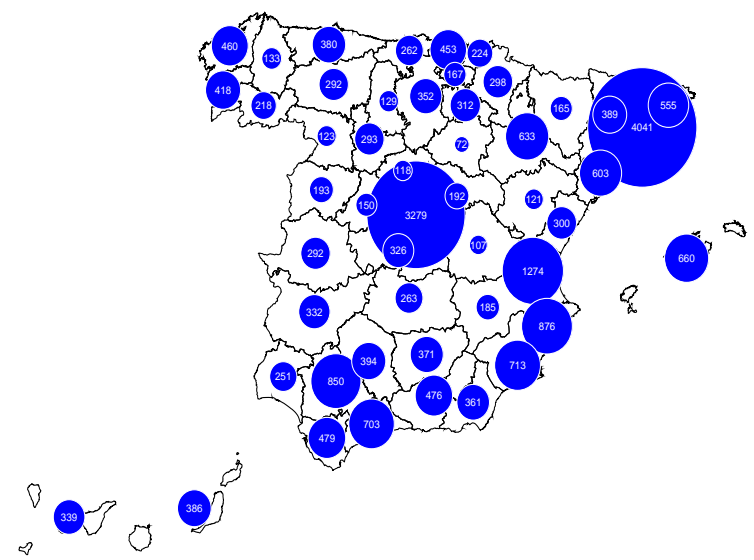

(d) Savings banks, 2008

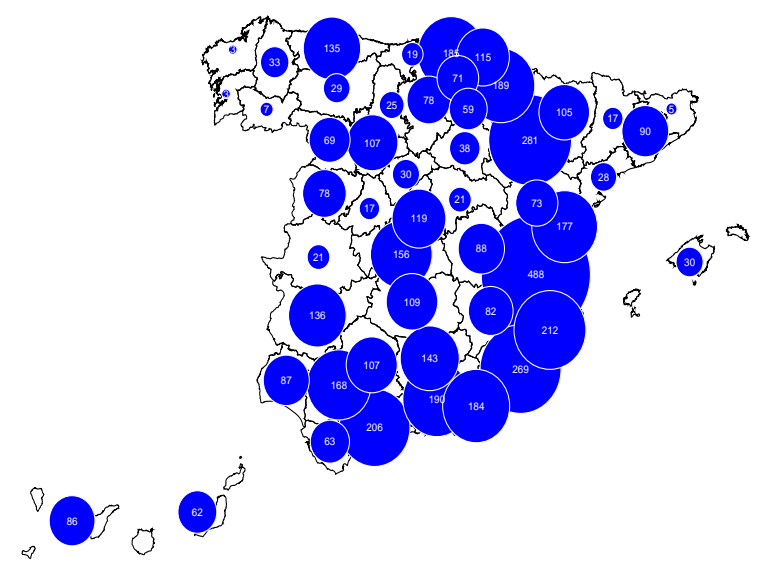

(f) Credit unions, 2008 
Figure 3: Branches per 10,000 inhabitants (NUTS level 3), Spanish banking sector, 1992 vs. 2008

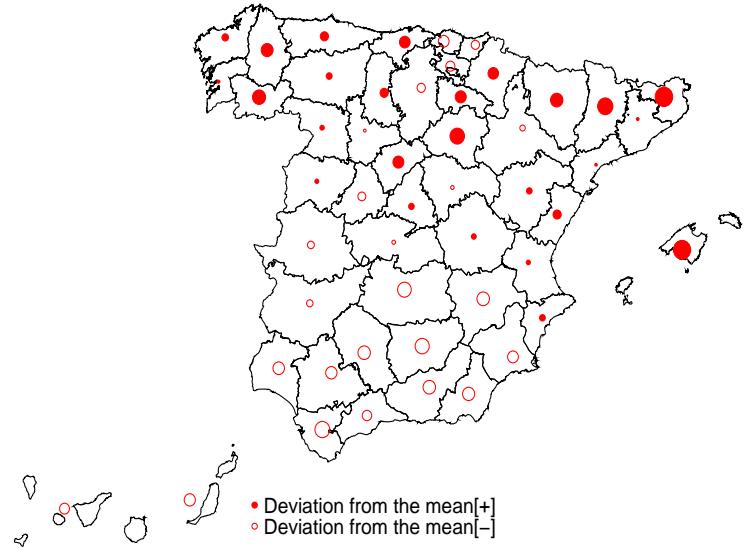

(a) Commercial banks, 1992

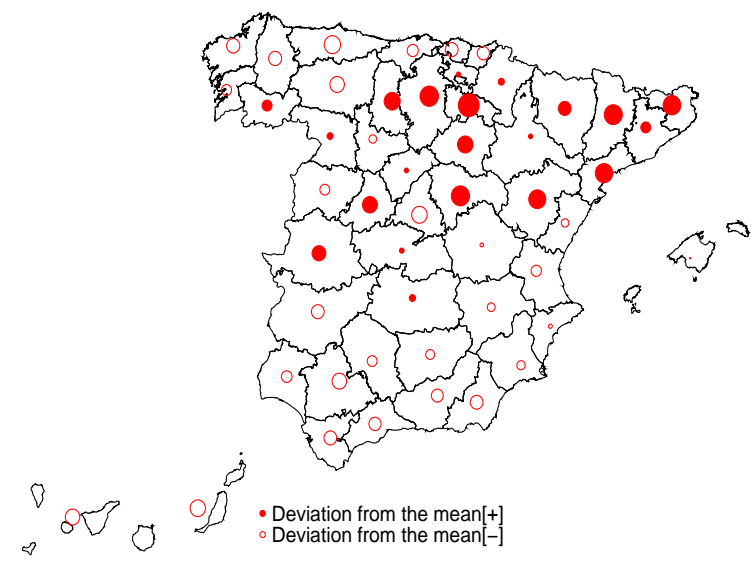

(c) Savings banks, 1992

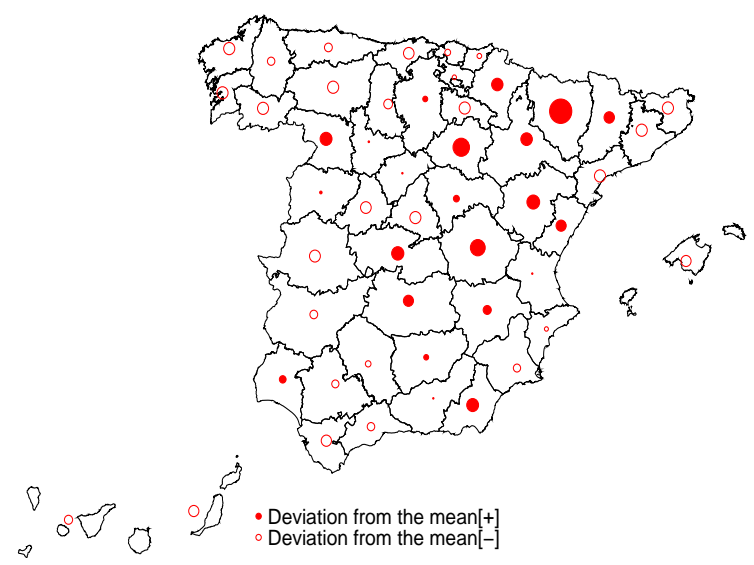

(e) Credit unions, 1992

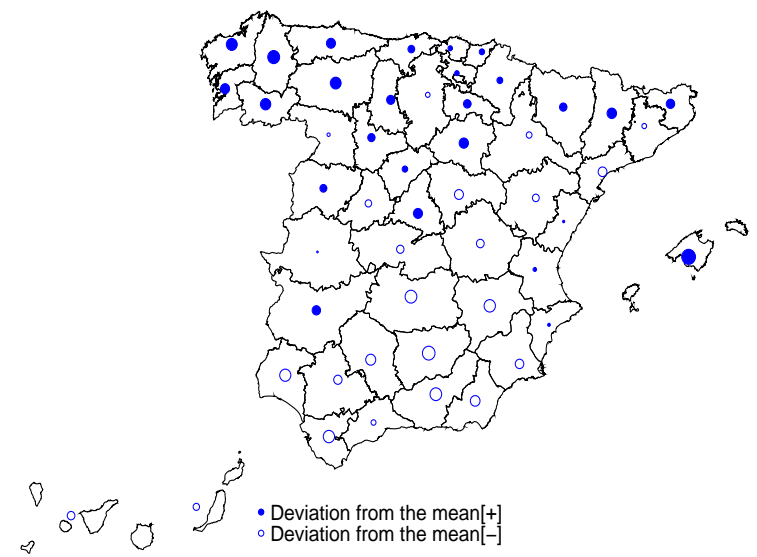

(b) Commercial banks, 2008

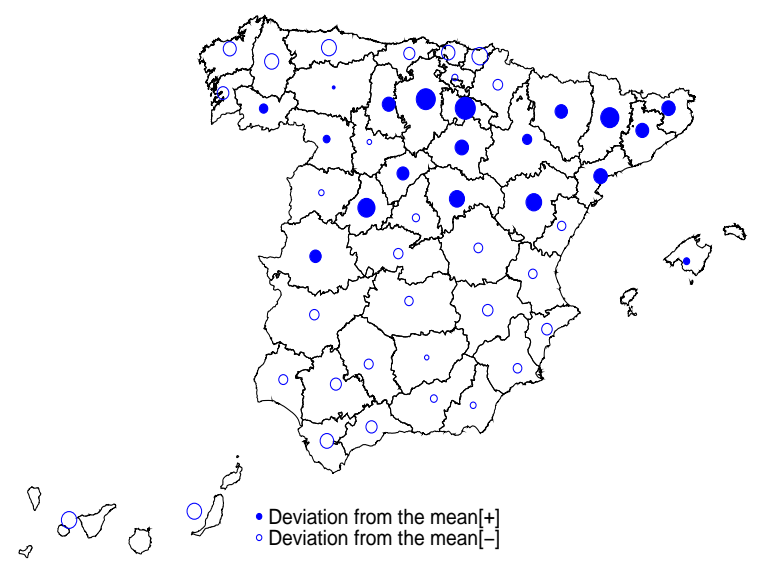

(d) Savings banks, 2008

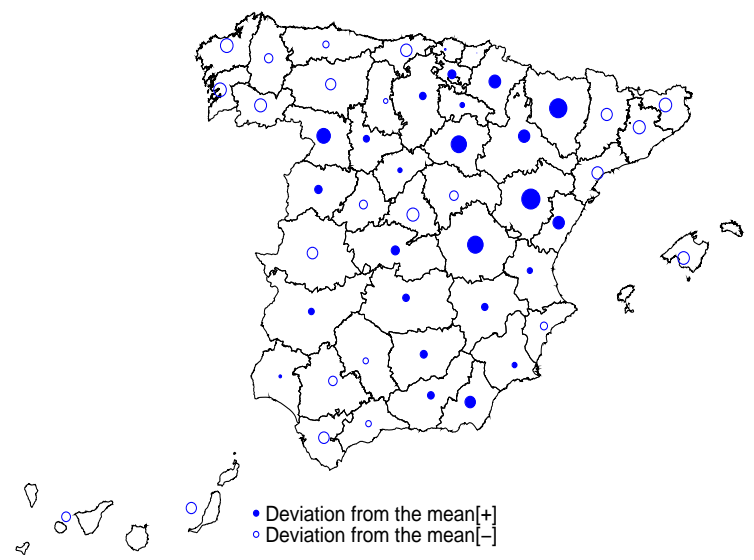

(f) Credit unions, 2008 
has been remarkable (Madrid).

In the case of savings banks, the aggregate results shown in Figure 1 are also corroborated. Analogously to the case with commercial banks, there are important differences between provinces, as shown in Figures $2 \mathrm{c}$ and $2 \mathrm{~d}$. Although, on average, the number of savings banks' branches has not doubled, this has been the case in several provinces. The greatest increase has occurred in Madrid, where the number of savings banks' branches has more than tripled (it was 969 by 1992 and 3,279 by 2008). In some other cases, the increases have also been remarkable, especially in the south (Andalusia), east (Valencia and Murcia), north-east (Catalonia) and the islands (both Canary and Balearic). Although this is a hypothesis that needs to be properly tested, these are precisely the provinces where construction has boomed most strongly. By contrast, the increases have been more moderate in the north-west (Galicia), Navarre and the Basque Country, and Castile (both Castile-Leon and Castile-La Mancha).

Credit unions' patterns are much different, because of their specific characteristics. Although either banks or savings banks were initially present in all provinces, in the case of credit unions there were remarkable differences between provinces, mostly because they have traditionally been linked to particular economic sectors (especially agriculture). Therefore, in some provinces, especially where these sectors were important, the number of branches has increased remarkably. However, for provinces where the importance of credit unions was minor, the number of credit union branches has increased moderately. This indicates that the branching strategies followed by these firms could have been defensive-indeed, there are some provinces where their presence was important in 1992 but is virtually the same in 2008, especially those where the presence of either commercial banks or savings banks has increased moderately.

The information in Figure 2 does not take into account not only that there are important differences in the number of inhabitants in each province but also that the development has also been different (Hierro and Maza, 2009, 2010). Some provinces' populations have increased sharply, either because of immigration of Spanish people from other areas or people from abroad, whereas in others this has not occurred. These migratory flows could be partly related to the disparate branching patterns, although this hypothesis should be properly tested. Figure 3 shows that, when taking this information into account, the differences between 1992 and 2008 are more moderate. In addition, in the particular case of savings banks (subfigures $3 \mathrm{c}$ and $3 \mathrm{~d}$ ) there are some regions, such as the Valencian Community (located on the east coast of Spain) where, despite undergoing some of the most impressive increases in the number of savings 
bank branches, the deviation from the mean is still negative.

\section{On the determinants of bank branch expansion}

\subsection{Sample description and selected variables}

According to the trends described in the preceding paragraphs, the existing heterogeneity of branching patterns and geographic expansion strategies has been remarkable. However, the difficult circumstances that are affecting some Spanish financial institutions since 2008, especially some savings banks, ${ }^{6}$ might suggest that not all geographic expansion strategies have been successful. Although the likely sources of trouble cannot be confined exclusively to the territorial expansion policies, given that those firms involved in mergers and acquisition processes are almost entirely savings banks (which are the institutions going through the deepest difficulties), it is natural to wonder whether the decisions to branch were appropriate.

In this study we focus in the socio-economic variables that may have influenced the decisions to expand geographically. As indicated earlier, previous literature on Spanish banking has mostly focused on competition issues, without an explicit interest in analyzing the links between geographic expansion and socio-economic variables. The only exception is the paper by Bernad et al. (2008), in which the authors analyze the possible long-term consequences of deregulation on financial exclusion in Spain. ${ }^{7}$ We build on Bernad et al.'s work, extending the set of determinants, uncovering a more recent period, and choosing techniques allowing a more accurate analysis of the determinants of the response variables. In addition, we split the results for the three types of financial institutions: commercial banks, savings banks and credit unions.

However, the information available at municipal level is scarce, both in terms of variables and years. For the sake of simplicity, the study is confined to year 2008. It could be extended to previous years but then some covariates would have had to be dropped from the analysis. In addition, the unavailability of information for many years makes it difficult to consider panel data techniques, and performing the analysis for more years would enlarge the quantity of reported tables to unreasonable proportions. ${ }^{8}$

We examine the impact of the selected covariates on the location decisions of banking

\footnotetext{
${ }^{6}$ Since the global financial crisis began the Bank of Spain has had to take over two savings banks, Caja Castilla-La Mancha (March 29 $9^{\text {th }}, 2009$ ) and Cajasur (May 22 $\left.{ }^{\text {nd }}, 2010\right)$.

${ }^{7}$ Carbó-Valverde and Rodríguez-Fernández (2004) also deal with financial exclusion issues in the Spanish banking sector, although their paper is much more focused on the finance-growth nexus. See also Carbó et al. (2003).

${ }^{8}$ These additional results are available from the authors upon request.
} 
firms. As indicated by Evanoff (1988), factors influencing the level of financial service accessibility, which we proxy by the number of bank branches available, include elements influencing consumer demand, and the degree of regulatory stringency imposed by banking authorities (Evanoff, 1988, p.194). Thus, the dependent variable is the total number of bank branches (proxying the demand for banking services), ${ }^{9}$ while the independent variables are related to demographic, economic, financial and environment indicators affecting the territorial unit being evaluated. The information used to run the regressions is at municipal level (former NUTS level 5 in European terminology, or LAU level 2 according to the new terminology). Using a smaller territorial unit, such as municipalities rather than provinces (NUTS level 3) or regions (NUTS level 2), is expected to reduce the problem posed by variation in population density characterizing some previous literature.

Our first set of variables is related to demography, likewise Lanzillotti and Saving (1969) and Evanoff (1988). Extending previous work by Bernad et al. (2008), we split the total population between natives (POP_ESP) and foreign-born immigrants (POP_FOREIGN). The inclusion of population stands with most previous literature. For instance, Lanzillotti and Saving (1969) makes the number of branches depend on three sets of variables: population, density of population, and income, according to which higher levels of population or income would contribute to increasing the number of branches via the increased demand for bank services. Evanoff (1988) concurs, arguing that both population and per capita income are expected to positively impact accessibility because they directly influence the demand for bank services. Splitting population between natives and foreign-born immigrants is related to previous literature analyzing the interactions between migration and regional income disparities, which generated a heated debate (Barro and Sala-i-Martin, 1992; Østbye and Westerlund, 2007; Shioji, 2001; Hierro and Maza, 2009, 2010). A number of recent papers have also been examining the links between immigrant banking and financial exclusion (Joassart-Marcelli and Stephens, 2010). However, although access to banking services is a critical issue for the economic success of individuals and the sustainability of communities, the amount of research focusing on immigrant communities is still relatively low. ${ }^{10}$

\footnotetext{
${ }^{9}$ We will refer to service accessibility and the existence of bank offices as synonymous. However, as indicated by Evanoff (1988), although most studies have used either the number of offices, or population per office as a proxy for measuring service accessibility, we should ideally take into account time, distance, and the cost necessary to obtain banking services as well.

${ }^{10}$ Splitting the total population between natives (POP_ESP) and foreign-born immigrants (POP_FOREIGN) does not per se postulate that the level of service provision is affected by whether the market served is foreign or domestic. The Spanish population has increased from less than 38 million by 1981 and less than 39 million by 1991 (official dates of releasing census data) to more than 46 million as of July, 2011. This suggested that, although
} 
Our second set of variables is related to economic activity. By contrast with previous studies which could use a specific measure of income at municipal level (Bernad et al., 2008), we cannot use the same variable because it is no longer available. Instead, the institution providing the information constructs a so-called "market share" variable as a weighted average of population, number of telephone lines, cars, trucks (trucks and vans), bank branches and retail commercial activities. We shall rule out this variable because some of its components are already included either as dependent or independent variables. So, should we be interested in using a specific measure of income we shall use proxies. Some variables can be considered in these respect, such as the total number of cars (CARS) in each municipality, or other variables such as the (average/median) cost of residential houses in each municipality. However, since both measures are less than perfect proxies for per capita income, we finally discarded their use. Our analysis, though, does include the other component of the VEHICLES variable (apart from $C A R S$ ), namely, the total number of vans and trucks (TRUCKS), because of their usually strict relation to productive activities. Sectoral activities are also considered in this category via the inclusion of industrial and construction activities (IND_CONS), commercial activities (both wholesale, COMM_WHOLE, and retail, COMM_RETAIL), and tourism (TOURISM). The inclusion of most of these variables is endorsed by several contributions such as Crawford (1973), who considers the geographic distribution of bank branches to be related to the expanded development of commercial activities, including the general growth of suburban population, the increase of per capita income, the widespread use of the automobile (resulting in greater customer mobility), or the rise in planned shopping centers (Crawford, 1973, p.353). These trends may further contribute to the number of branches increasing much more rapidly than population in some particular places.

The third set of covariates are financial variables. Although a thorough examination of bank competition issues lies beyond the aims of this paper, as indicated in the introduction there are several contributions which have dealt with bank branching patterns and competition issues in Spain. Some other authors have investigated the existence of rational herding in various arenas of economic activity, including bank branching patterns. Specifically, Chang et al. (1997) have empirically explored whether the apparent clustering of bank branches in New York City

population had been stagnant for many years until the mid 1990s, its growth rates increased hand-in-hand with the economic surge of the last fifteen years, basically due to the arrival of immigrants. Therefore, our aim is rather to test whether some of these foreign-born communities could have been excluded from the bank branch geographic expansion policies. The rationale for this could relate to reasons such as the higher probability of default in case of losing the job (given their lower family ties), their generally lower salaries, or some others such as those indicated by Joassart-Marcelli and Stephens (2010) which would include also education, legal status or English (in our case Spanish) ability. 
between July, 1990 and June, 1995 could be at least partially attributed to "rational herding" by banks. Rational herding refers to situations where it is individually rational for agents/firms to mimic the actions of others even though such mimicry can potentially lead to aggregate outcomes that are suboptimal. In the case of bank branching patterns in Spain, which led the number of total offices to increase proportionally higher than the GDP (especially in the case of savings banks), this type of behavior might have also existed. We therefore consider that the existence of the other types of financial institution may influence the location of the others, i.e., once savings banks were allowed to branch freely, some institutions might have decided to locate where other financial institutions had been settled for years. However, the plausible explanations to explain banks' behavior could also be related to "rival precedence". In the particular case of banking, Hannan and McDowell (1987) found that the adoption of automatic teller machines by rivals increased the conditional probability that a banking firm adopted such an innovation.

Finally, we also consider population density (DENSITY, measured as inhabitants per square kilometer). Low population density areas might, a priori, be expected to be associated with few bank branches. However, some previous studies found that reductions in legal restrictions on banks to expanding geographically led to enhanced accessibility of banking services in rural areas, where bank branches are relatively sparse (Gunther, 1997). This lived up to the promise of enhanced service accessibility in rural areas after geographic banking liberalizations in the US. ${ }^{11}$ While some papers such as Gunther (1997), found the lifting of geographic restrictions to be positively associated with relatively strong growth in the number of bank branches serving rural areas, others (Evanoff, 1988) found similar trends for both metropolitan (where population density is generally high) and rural areas (where population density is generally low). Indeed, as indicated by Evanoff (1988), the influence of the distribution of the population within the unit of observation is not obvious. On one hand, the more concentrated the population the lower the transport costs for obtaining services i.e., more services (branches) are demanded. On the other hand, the fewer the number of branches, the greater the concentration population when economies exist in serving clients. Given this ambiguity, previous studies generally found either negative or non-significant coefficients. In our case, although previous studies applied to the Spanish banking sector have found an average negative correlation between population density and the number of bank branches, we will re-

\footnotetext{
${ }^{11}$ However, previous literature did not find the extent of branching permitted to be relevant in determining service accessibility. See, for instance, Gilbert (1974), Savage and Humphrey (1979), or Seaver and Fraser (1979).
} 
examine the question, given that the interpretation of results may be intricate. Table 4 provides correlation coefficients for the variables of interest.

Our data are provided by Fundació La Caixa, who publishes the Spanish Economic Yearbook (Anuario Económico de España). The data contain information on the number of branches belonging to commercial banks, savings banks, and credit unions (years 2007 and 2008) per municipality, for towns with more than 1,000 population-which represent roughly $96 \%$ of total population in Spain. Likewise Bernad et al. (2008), our unit of analysis is the municipality due to the local nature of banking activities. Summary statistics on the selected variables are reported in Table 3.

\subsection{Empirical findings}

\subsubsection{Ordinary-least-squares results}

The model to be estimated using OLS is:

$$
\begin{gathered}
\log (\text { BRANCHES })=\beta_{0}+\beta_{1} \log (\text { POP_ESP })+\beta_{2} \log (\text { POP_FOREIGN })+\beta_{3} \text { UNEMPLOY } \\
+\beta_{4} \log (\text { TRUCKS })+\beta_{5} \log (\text { IND_CONS })+\beta_{6} \log (\text { COMM_WHOLE }) \\
+\beta_{7} \log (\text { COMM } \\
\text { ETAIL })+\beta_{8} \log (\text { TOURISM })+\beta_{9} \log (\text { DENSITY })+\varepsilon
\end{gathered}
$$

where each coefficient refers to the variables described in section 3 , and $\varepsilon$ is the error term, assumed to be normally distributed. Results are reported separately for all banking firms, commercial banks and savings banks in the different columns of Table 5. All estimations have been performed for year 2008. However, in order to take into account the rival precedence hypothesis, Models 2, 3 and 4 include the lagged number of branches of the different types of banking firms among the selected of covariates (one period-lag, i.e., year 2007 information). This strategy follows some of the ideas by Hannan and McDowell (1987), whose study on the adoption of automatic teller machines by banks included information on their adoption by rivals in the previous year $(t-1)$. This and related pieces of information aim to capture the degree to which a firm has been preceded in the market.

The demographic variables, both POP_ESP and POP_FOREIGN, are mostly significant throughout at the one-percent significance levels and have the expected (average) signs. The impact of the native population (POP_ESP) on the number of bank offices of the average municipality is positive and significant regardless of the type of firm considered-commercial 
Table 3: Descriptive statistics of the variables of interest, 2008

\begin{tabular}{llrrrrrrr}
\hline & Variable & Mean & Median & Std.dev. & $1^{\text {st }}$ quartile & $3^{\text {rd }}$ quartile & Maximum & Minimum \\
\hline & POP_ESP & $36,476.75$ & $3,272.00$ & $279,553.99$ & $1,684.50$ & $8,479.50$ & $7,578,941.00$ & 349.00 \\
& POP_FOREIGN & $4,727.86$ & 241.00 & $43,189.81$ & 79.00 & 819.25 & $1,103,790.00$ & 0.00 \\
& UNEMPLOY & 4.67 & 4.30 & 2.02 & 3.30 & 5.70 & 17.20 & 0.70 \\
Socioeconomic & TRUCKS & $4,541.31$ & 527.00 & $34,326.85$ & 274.00 & $1,249.25$ & $894,689.00$ & 5.00 \\
variables & IND_CONS & 698.91 & 81.00 & $5,392.43$ & 40.00 & 197.25 & $160,673.00$ & 0.00 \\
& COMM_WHOLE & 172.73 & 12.50 & $1,375.21$ & 5.00 & 37.00 & $35,654.00$ & 0.00 \\
& COMM_RETAIL & 884.38 & 63.00 & $6,603.69$ & 28.00 & 212.25 & 178,431 & 0.00 \\
& TOURISM & 89.64 & 1.00 & 792.54 & 0.00 & 5.00 & $18,501.00$ & 0.00 \\
& DENSITY & 40.08 & 4.00 & 312.50 & 2.00 & 8.00 & $8,103.00$ & 0.00 \\
\hline & BRANCHES & 394.34 & 68.49 & $1,311.58$ & 27.73 & 233.76 & $22,193.00$ \\
Financial variables & BANKS & 13.99 & 1.00 & 110.67 & 0.00 & 4.00 & $2,585.00$ & 0.00 \\
& SAVINGS & 21.81 & 2.00 & 182.12 & 1.00 & 4.00 & $5,561.00$ \\
& UNIONS & 4.28 & 1.00 & 33.81 & 0.00 & 1.00 & $1,129.00$ \\
\hline
\end{tabular}

Source: Spanish Economic Yearbook (Anuario Económico de España, La Caixa Foundation).

${ }^{a}$ In percentage.

${ }^{b}$ Number of industrial activities, including construction.

${ }^{c}$ Number of wholesale commercial activities. It is a fair proxy for the number of wholesale commercial businesses.

$\mathrm{d}$ Number of retail commercial activities, which is equivalent to the number of retail commercial licenses. It is a fair proxy for the number of retail commercial businesses.

e Relative index of the touristic importance of each municipality.

${ }^{\mathrm{f}}$ Inhabitants $/ \mathrm{km}^{2}$.

$\mathrm{g}$ Number of branches. 
Table 4: Correlation coefficients (Pearson) among the variables of interest, 2008

\begin{tabular}{|c|c|c|c|c|c|c|c|c|c|}
\hline & POP_ESP & POP_FOREIGN & UNEMPLOY & TRUCKS & IND_CONS & COMM_WHOLE & COMM_RETAIL & TOURISM & DENSITY \\
\hline POP_ESP & 1.0000 & 0.9215 & 0.0366 & 0.9880 & 0.9677 & 0.9859 & 0.9943 & 0.8262 & 0.0610 \\
\hline POP_FOREIGN & 0.9215 & 1.0000 & 0.0127 & 0.9368 & 0.9416 & 0.9544 & 0.9185 & 0.8241 & 0.0700 \\
\hline UNEMPLOY & 0.0366 & 0.0127 & 1.0000 & 0.0365 & 0.0173 & 0.0303 & 0.0376 & 0.0383 & 0.0729 \\
\hline TRUCKS & 0.9880 & 0.9368 & 0.0365 & 1.0000 & 0.9650 & 0.9789 & 0.9872 & 08558 & 00401 \\
\hline IND CONS & 0.9677 & 0.9416 & 0.0173 & 0.9650 & 1.0000 & 0.9839 & 0.9745 & 0.7992 & 0.0513 \\
\hline COMM_RETAIL & 0.9943 & 0.9185 & 0.0376 & 0.9872 & 0.9745 & 0.9847 & 1.0000 & 0.8429 & 0.0630 \\
\hline TOURISM & 0.8262 & 0.8241 & 0.0383 & 0.8558 & 0.7992 & 0.8277 & 0.8429 & 1.0000 & 0.0637 \\
\hline DENSITY & 0.0610 & 0.0700 & 0.0729 & 0.0401 & 0.0513 & 0.0704 & 0.0630 & 0.0637 & 1.0000 \\
\hline
\end{tabular}


Table 5: Determinants of bank branch location, all banking firms, 2008 (information at LAU level 2, formerly NUTS level 5)

\begin{tabular}{|c|c|c|c|c|}
\hline & Model 1 & Model 2 & Model 3 & Model 4 \\
\hline & $\begin{array}{c}\text { Dependent variable: } \\
\text { Number of bank } \\
\text { branches }\end{array}$ & $\begin{array}{c}\text { Dependent variable: } \\
\text { Number of } \\
\text { commercial banks' } \\
\text { branches } \\
\end{array}$ & $\begin{array}{c}\text { Dependent variable: } \\
\text { Number of savings } \\
\text { banks' branches }\end{array}$ & $\begin{array}{l}\text { Dependent variable } \\
\text { Number of credit } \\
\text { unions' branches }\end{array}$ \\
\hline (Intercept) & $\begin{array}{c}-2.873^{* * *} \\
(0.089)\end{array}$ & $\begin{array}{c}-1.760^{* * *} \\
(0.117)\end{array}$ & $\begin{array}{c}-2.344^{* * * *} \\
(0.104)\end{array}$ & $\begin{array}{c}-1.499^{* * * *} \\
(0.152)\end{array}$ \\
\hline POP_ESP & $\begin{array}{l}0.397^{* * *} \\
(0.020)\end{array}$ & $\begin{array}{l}0.203^{* * *} \\
(0.024)\end{array}$ & $\begin{array}{l}0.322^{* * *} \\
(0.022)\end{array}$ & $\begin{array}{l}0.239^{* * *} \\
(0.031)\end{array}$ \\
\hline POP_FOREIGN & $\begin{array}{l}0.075^{* * *} \\
(0.007)\end{array}$ & $\begin{array}{l}0.007 \\
(0.008)\end{array}$ & $\begin{array}{l}0.051^{* * * *} \\
(0.007)\end{array}$ & $\begin{array}{l}0.045^{* * *} \\
(0.010)\end{array}$ \\
\hline UNEMPLOY & $\begin{array}{c}-0.020^{* * * *} \\
(0.004)\end{array}$ & $\begin{array}{c}-0.022^{* * *} \\
(0.004)\end{array}$ & $\begin{array}{c}-0.003 \\
(0.004)\end{array}$ & $\begin{array}{c}-0.009 \\
(0.005)\end{array}$ \\
\hline TRUCKS & $\begin{array}{r}-0.037 \\
(0.019)\end{array}$ & $\begin{array}{c}-0.159^{* * *} \\
(0.021)\end{array}$ & $\begin{array}{c}0.021 \\
(0.019)\end{array}$ & $\begin{array}{l}0.140^{* * *} \\
(0.027)\end{array}$ \\
\hline IND_CONS & $\begin{array}{l}0.102^{* * *} \\
(0.017)\end{array}$ & $\begin{array}{l}0.148^{* * *} \\
(0.019)\end{array}$ & $\begin{array}{l}0.106^{* * *} \\
(0.017)\end{array}$ & $\begin{array}{c}-0.156^{* * *} \\
(0.024)\end{array}$ \\
\hline COMM_WHOLE & $\begin{array}{c}0.018 \\
(0.012)\end{array}$ & $\begin{array}{l}0.051^{* * *} \\
(0.013)\end{array}$ & $\begin{array}{r}-0.028^{*} \\
(0.012)\end{array}$ & $\begin{array}{l}0.080^{* * *} \\
(0.017)\end{array}$ \\
\hline COMM_RETAIL & $\begin{array}{l}0.217^{* * *} \\
(0.014)\end{array}$ & $\begin{array}{l}0.192^{* * *} \\
(0.016)\end{array}$ & $\begin{array}{r}-0.033^{*} \\
(0.015)\end{array}$ & $\begin{array}{r}-0.047^{*} \\
(0.021)\end{array}$ \\
\hline TOURISM & $\begin{array}{l}0.073^{* * *} \\
(0.006)\end{array}$ & $\begin{array}{l}0.085^{* * *} \\
(0.007)\end{array}$ & $\begin{array}{l}0.077^{* * *} \\
(0.007)\end{array}$ & $\begin{array}{c}-0.030^{* *} \\
(0.009)\end{array}$ \\
\hline DENSITY & $\begin{array}{c}-0.063^{* * *} \\
(0.006)\end{array}$ & $\begin{array}{c}-0.018^{* *} \\
(0.007)\end{array}$ & $\begin{array}{c}-0.018^{* *} \\
(0.006)\end{array}$ & $\begin{array}{c}-0.156^{* * *} \\
(0.008)\end{array}$ \\
\hline SAVINGS 2007 & & $\begin{array}{l}0.302^{* * *} \\
(0.018)\end{array}$ & & $\begin{array}{l}0.249^{* * *} \\
(0.023)\end{array}$ \\
\hline UNIONS $_{2007}$ & & $\begin{array}{l}0.050^{* * *} \\
(0.014)\end{array}$ & $\begin{array}{l}0.137^{* * *} \\
(0.012)\end{array}$ & \\
\hline$B A N K S_{2007}$ & & & $\begin{array}{l}0.260^{* * * *} \\
(0.015)\end{array}$ & $\begin{array}{l}0.089^{* * *} \\
(0.022)\end{array}$ \\
\hline$R^{2}$ & 0.908 & 0.882 & 0.889 & 0.612 \\
\hline $\bar{R}^{2}$ & 0.908 & 0.882 & 0.889 & 0.611 \\
\hline$F$ & $3,635.739$ & $2,253.129$ & $2,422.479$ & 474.895 \\
\hline$N$ & 3,324 & 3,324 & 3,324 & 3,324 \\
\hline
\end{tabular}


bank (Model 2) or savings bank (Model 3). If we also include credit unions, which are considered in the regression corresponding to Model 4, the sign and significance of the impact is mostly maintained.

The financial integration of immigrants into mainstream banks can be partly assessed via the POP_FOREIGN variable, whose sign is also positive and significant throughout for all banking firms (Model 1) and savings banks (Model 3), but not for commercial banks (Model 2), in the case of which significance is entirely lost. In addition, the magnitude of the coefficients is much larger for savings banks (Model 3) than for commercial banks (Model 2). As indicated by Joassart-Marcelli and Stephens (2010), the processes leading to financial exclusion are much more complex, but our results suggest that savings banks (and also credit unions, which are included in Model 4) contribute more to the financial inclusion of foreign-born immigrants than commercial banks, reinforcing and extending previous results from Bernad et al. (2008), where population was not split between natives and foreign-born immigrants.

The set of economic performance variables includes unemployment (UNEMPLOY). Given its generally high negative correlation with per capita income, and, given that previous studies analyzing the impact of per capita income on service accessibility have found the expected positive signs (Evanoff, 1988), UNEMPLOY is significant and negative when considering all banking firms (Model 1), in line with previous findings in the literature. However, in the case of savings banks the impact is not only lower but also non-significant (Model 3), endorsing previous results from Bernad et al. (2008), who indicated that this type of banks clearly alters the geography of financial exclusion. Therefore, the restructuring process which are now affecting the Spanish savings banks' industry could might have a dark side given the (still) relevant role of these firms for financial inclusion.

The economic activity variables, including the number of trucks (TRUCKS), industrial and commercial activities (IND_CONS), commercial activities (both wholesale and retail, COMM_WHOLE and COMM_RETAIL), and tourism (TOURISM) have different signs and significance for the different financial institutions considered. In general, IND_CONS, COMM_RETAIL and TOURISM are positive and significantly related to the total number of bank branches, regardless of the type of institution considered, as one might reasonably expect (Model 1).

Wholesale commercial activities (COMM_WHOLE) have also a positive and significant impact for commercial banks (Model 1 in Table 5). This finding stands with the traditional stronger linkages observed between commercial banks and private firms, whereas savings 
banks have traditionally had stronger ties with families and regional and local governments, and government's dependent institutions. Although industrial and construction activities (IND_CONS) cannot be broken down, their significance and positive signs, for both commercial (Model 2) and savings banks (Model 3), might indicate that both types of banks have been feeding the housing boom affecting Spain until late 2007.

Regarding TRUCKS, its sign and significance are unclear for all banking firms (Table 5, Model 1) due to the opposite patterns for commercial (Model 2) and savings banks (Model 3). For commercial banks the impact is negative and significant reflecting their lack of presence in rural areas (where this type of vehicles abound, given this category also includes vans and tractors), whereas, in the case of credit unions (Table 5, Model 4), the impact is strongly positive and significant, showing the opposite pattern.

The environmental variable, DENSITY (in our case, number of inhabitants per square kilometer) is negative throughout, for all models (types of firms) considered. It therefore corroborates previous findings for the Spanish case (Bernad et al., 2008). The comparison with the US case is more intricate because the corresponding literature is larger, and different studies have used alternative measures of population distribution (density). Even though, the coefficients obtained have been generally either negative-like us—or not significant (Evanoff, 1988).

The rival precedence hypothesis (Hannan and McDowell, 1987) is partly tested by including the number of branches corresponding to the other types of institutions among the regressors - they were therefore included only in Models 2, 3 and 4 in Table 5. All variables are positive and significant for all types of firms. Although properly testing for the existence of rival precedence behavior would require a more thorough analysis, our findings suggests that, although the variables determining the location of bank branches do not coincide between the types of bank, the location decisions are not specific for each type of banking firm. This is especially apparent between commercial banks and savings banks. In the case of credit unions, the comparison with commercial banks suggests that some complementarities might exist. ${ }^{12}$

\subsection{Evaluating the determinants of geographic expansion using regression quantiles}

As indicated by Cade and Noon (2003), quantile regression (Koenker and Bassett, 1978; Koenker, 2001,2005 ) is a way to estimate the conditional quantiles of a response variable distribution (in

\footnotetext{
${ }^{12}$ A related hypothesis is the "rational herding" behavior referred to by Chang et al. (1997). Although tests for this alternative hypothesis bear similarities with testing for rival precedence, we consider the latter theory reflects more closely the behavior of Spanish banking firms. We thank a referee for this suggestion.
} 
our case, the number of bank branches in each municipality) in a linear model that provides a more complete view of possible causal relationships between variables in economic processes. In a number of instances, estimation of linear models by quantile regression may be preferable for a wide variety of reasons. The linear models specified in the previous section, which are common across economic empirical studies, provide information on average impacts, i.e., the average impact for the average municipality. Therefore, the researcher can only conclude whether this mean effect of a covariate on a response variable is significant or not. However, there is no reason why the impact should be the same over the entire conditional distribution (Coad and Hölzl, 2009). For instance, as indicated by Cunningham (2003), the determinants of growth for developed and developing countries-i.e., the tails of the distribution of the response variable-can differ remarkably. Rioja and Valev $(2004 a, b)$ deal with the links between financial development and economic growth from similar perspectives.

Quantile regression makes it possible to approach these and related issues with precision. Applications are growing in a variety of fields (see, for instance, the survey by Buchinsky, 1998), but they are still largely outnumbered by those using linear models which focus exclusively on average behavior, although this is, of course, a relevant approach. Therefore, as its own name suggests, quantile regression does not confine the analysis to regression against averages (and hence it is not limited in its explanatory values) but rather also uses information obtained from the underlying distribution of the dependent variable.

The advantages of quantile regression with respect to OLS are more apparent if we consider that, for a given a set of covariates, the linear regression models specify the conditionalmean function, whereas quantile regression models specify the conditional-quantile function. In practical terms, this implies that whereas OLS focuses on modeling the conditional mean of a response variable without accounting for the full conditional distribution properties of the response variable, the quantile regression model facilitates analysis of the conditional distributional properties of the response variable. In addition, both OLS and quantile regression models differ on their assumptions about the error terms. Social sciences are usually plagued with "nonstandard" conditions such as non-normal or heteroskedastic data. Non-financial data such as (conditional) income distribution are seldom normal—rather, they are bi-modal, as shown by Quah (1996). Financial or management data such as the dispersion of the annual compensation of chief executive officers tends to increase with firm size, an indicator of heteroskedasticity.

In this and related scenarios quantile regression might be more appropriate, no only be- 
cause it relaxes important assumptions for linear models such as those referred to above but also because of offering a much broader view than classical regression, as it takes also into account the effect of the explanatory variables on the (central and noncentral) location, scale, and shape of the distribution of the response variable. In contrast, the conditional-mean framework, when summarizing the response for fixed values of predictor variables cannot be readily extended to noncentral locations-where the interests of social science often reside. These and related ideas gained popularity since the seminal contribution of (Bassett and Koenker, 1978; Koenker, 2005), but the underlying thoughts go back to 1760 when the Croatian Jesuit Rudjer Josip Boscovich went to London for computational advice for his method of median regression-which was ultimately unsuccessful until relatively recent times. However, as stated by Hao and Naiman (2007), conditional-mean modeling has been applied widely in the social sciences (particularly in the past half century), and regression modeling of the relationship between a continuous response and covariates via OLS is now conceived as a crucial tool.

Finally, quantile regression goes beyond location and scale effects of the covariates on the response, asking how changes in the predictors might affect the underlying shape of the distribution of the response variable (Hao and Naiman, 2007). Much social science research focuses on social stratification and inequality, which are close areas to financial exclusion, that require a detailed analysis of the properties of a distribution. Given that central location, scale, skewness, and other higher-order properties characterize a distribution, it is easily inferred that conditional-mean models are ill-equipped to characterize the links between a response distribution and the covariates.

In our particular case, one of the most important advantages of quantile regression is that it enables to considering the entire distribution of bank branch locations, either for all banking firms or for the three types of firms separately. As indicated by Coad and Hölzl (2009), quantile regression is able to provide a more complete story of the relationship between variables-in our case, between bank branch location and the relevant covariates. We can therefore specifically investigate whether, for municipalities where the number of bank branches is low (corresponding to the lower tail of the distribution, or to the lower quantiles), the sign and significance of the determinants is the same as for other municipalities where the number of bank branches is high (those lying in the higher tails of the distribution, and corresponding to the highest quantiles).

Under such circumstances, we would be able to design specific policies for those municipal- 
ities where access to financial services is more difficult in terms of number of bank branches. Therefore, in the present study we think that both over- and under-branched municipalities (especially the latter) are of interest in their own right-we do not want them to consider as outliers-and quantile regression allows us to analyze them in greater detail. In addition to this, as indicated by Coad and Hölzl (2009), we know that the standard least-squares assumption of normally distributed errors does not hold for our data because the location patterns follow a fat-tailed distribution-see figure. However, as indicated by Buchinsky (1998), while standard regression estimators are not robust to departures from normality, the quantile regression estimator is characteristically robust to outliers on the dependent variable, as indicated earlier. As stated above as well, quantile regression also relaxes the restrictive assumption that error terms are identically distributed at all points of the conditional distribution and, avoiding this assumption will enable to analyze differences in the relationship between the endogenous and exogenous variables at different points of the conditional distribution of the dependent variable.

In some particular fields these instruments can be particularly important. For instance, they are related to the issue of parameter variability and the expansion method developed by Casetti (1972) and his followers (Foster, 1991; Eldridge and Jones, 1991; Jones, 1992; Jones and Bullen, 1994), a modeling strategy which takes into account contextual variation of parameters and functional forms. Casetti (1972) expanded the traditional econometric model to include a set of equations that would relate the parameters of the regression equation to crosssectional spatial characteristics (Kochanowski, 1990). Although the discussion of this issue has evolved significantly and the state of the art now centers on geographically weighted regression (Fotheringham et al., 2002), the underlying ideas are still valid and strongly related to our research questions. Indeed, some recent papers such as Basile and Girardi (2010), who test (and reject) the assumption of parameter homogeneity across geographic units in the particular context of risk sharing measurement. Likewise, quantile regression allows testing whether the differences in both the magnitude and sign of the estimated coefficients for the different quantiles are significant or not.

Compared with respect the basic ordinary-least-squares model specified in Equation (1), the regression quantiles we use in this section specify the $\tau^{\text {th }}$ quantile of the conditional distribution of $y_{i}$ given $x$ as a linear function of the covariates. As described by Koenker and Bassett (1978), and in much greater detail in Koenker (2005), the estimation is carried out by 
minimizing the following equation:

$$
\operatorname{Min}_{\boldsymbol{\beta} \in \mathbb{R}^{k}} \sum_{i \in\left\{i: y_{i} \geq x^{\prime} \beta\right\}} \tau\left|y_{i}-\boldsymbol{x}^{\prime} \boldsymbol{\beta}\right|+\sum_{i \in\left\{i: y_{i}<\boldsymbol{x}^{\prime} \boldsymbol{\beta}\right\}}(1-\tau)\left|y_{i}-\boldsymbol{x}^{\prime} \boldsymbol{\beta}\right|
$$

where $k$ is the number of explanatory variables, and $\tau$ represents the vector containing each quantile. The vector of coefficients $\beta$ to be estimated will differ depending on the particular quantile.

Using regression quantiles has certain analogies with approaches such as that of Basile and Girardi (2010), who test the assumption of parameter homogeneity across geographic units in measuring risk sharing. In our case, running the regressions for different quantiles $\left(\tau^{\prime} \mathrm{s}\right)$ is equivalent, since the different values of $\tau$ refer to different values of the endogenous variable (number of bank branches), which varies between municipalities.

Results for the quantile regression estimation are provided in Tables 6, 7 and 8 for all banking firms (including credit unions), commercial banks, and savings banks, respectively. These tables provide coefficients and standard errors for selected quantiles $(\tau=$ $\{.05, .10, .25, .50, .75, .90, .95\})$. Please note that the quantile $\tau=.5$ refers to the median of the conditional distribution. Whilst OLS regressions report regression estimates based on the mean, quantile regression based on $\tau=.5$ provides an analogous result for a different moment of the distribution-the median. Therefore, whereas in the median-regression model the conditional $.5^{\text {th }}$ quantile is modeled as a function of covariates, quantile regression considers other quantiles to describe noncentral positions of the distribution. The results in Tables 6 through 8 go further, reporting results not only for the median $(\tau=.5)$ but also for other quantiles and, therefore, are more informative. We have also included Table 9 which reports information on the statistical differences among the slope coefficients for the different values of $\tau$.

The informativeness of the results is further improved by Figures 4 through 6, which provide continuous counterparts to Tables 6-8-i.e., for all possible values of $\tau$. Each plot in each figure depicts one coefficient of the quantile regression model (2). The dotted black line in each plot represents the point estimates, $\left\{\hat{\beta}_{j}(\tau): j=1, \ldots, 10\right\}$, with the shaded gray area depicting $90 \%$ pointwise confidence band. Superimposed on each plot is a red line representing the OLS estimate of the mean effect, with two dashed lines in red again representing a $90 \%$ confidence interval for this coefficient. The solid line in black on each plot indicates the null effect $\left(\hat{\beta}_{j}=0\right)$ and, therefore, when the area in grey does not overlap with the $\hat{\beta}_{j}=0$ solid black line the coefficient is significant at the $10 \%$ level. 
Figure 4: Determinants of bank branch location, all banking firms, regression quantiles, 2008

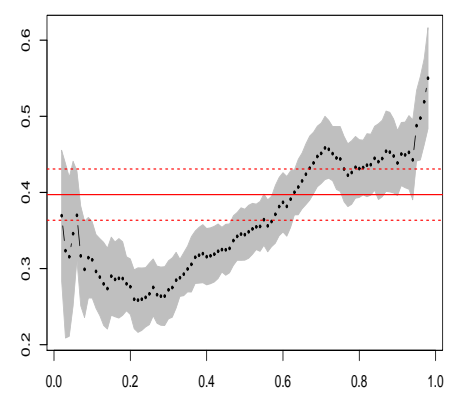

(a) POP_ESP

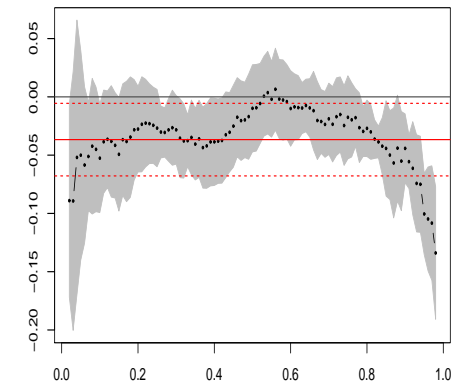

(d) TRUCKS

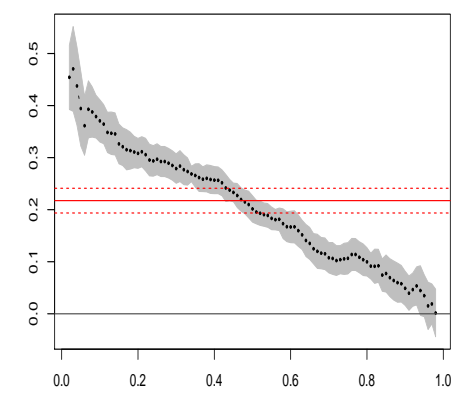

(g) COMM_RETAIL

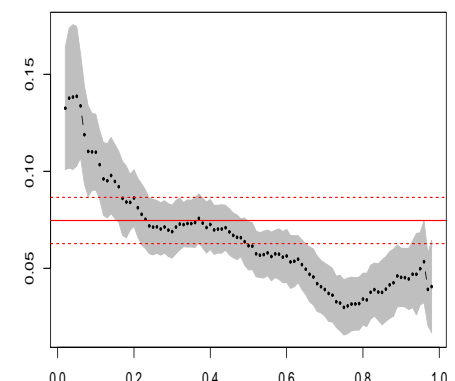

(b) POP_FOREIGN

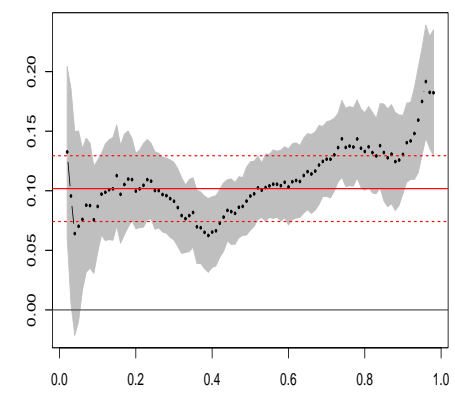

(e) IND_CONS

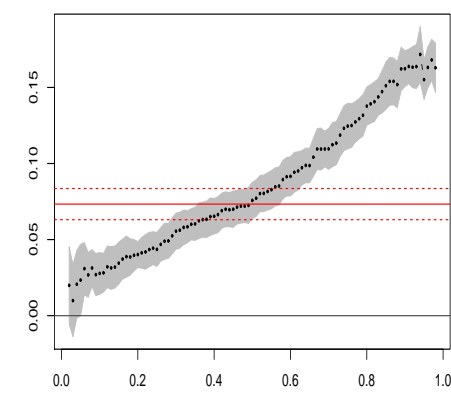

(h) TOURISM

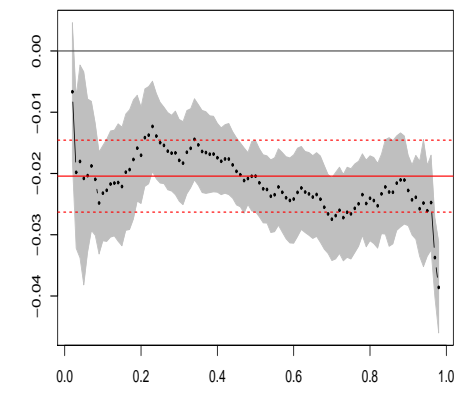

(c) UNEMPLOY

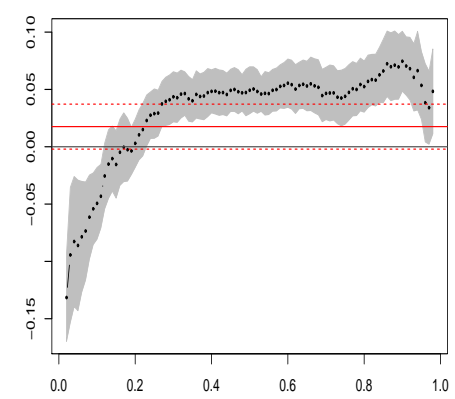

(f) COMM_WHOLE

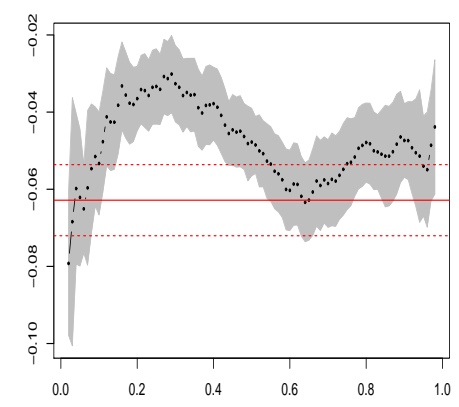

(i) DENSITY

Notes: The dotted black line in each subfigure represents the point estimates, $\left\{\hat{\beta}_{j}(\tau): j=1, \ldots, 10\right\}$, with the shaded gray area depicting $90 \%$ pointwise confidence band. Superimposed on each plot is a red line representing the OLS estimate of the mean effect, with two dashed lines in red again representing a 90\% confidence interval for this coefficient. The solid line in black on each plot indicates the null effect $\left(\hat{\beta}_{j}=0\right)$ and, therefore, when the area in grey does not overlap with the $\hat{\beta}_{j}=0$ solid black line the coefficient is significant at the $10 \%$ level. 
Figure 5: Determinants of bank branch location, commercial banks, regression quantiles, 2008

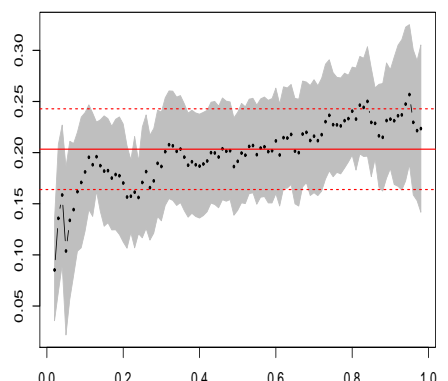

(a) POP_ESP

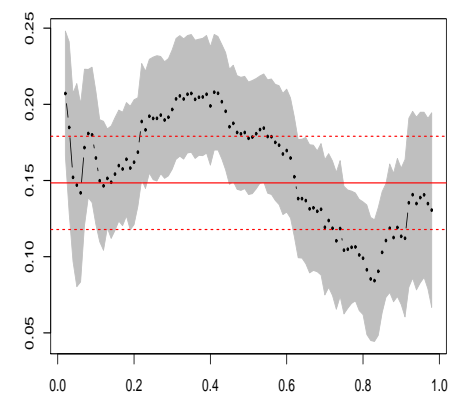

(e) IND_CONS

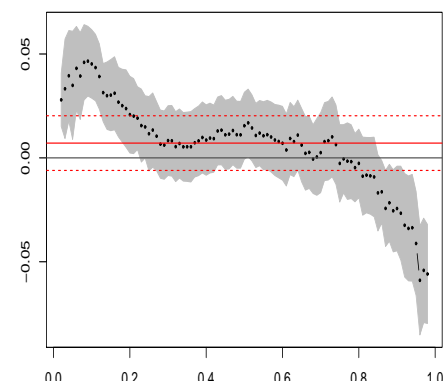

(b) POP_FOREIGN

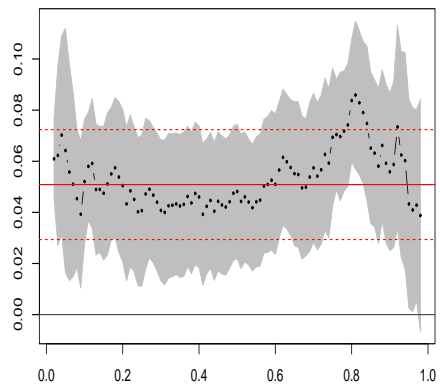

(f) COMM_WHOLE

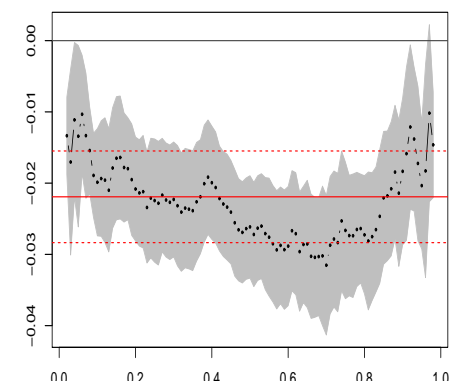

(c) UNEMPLOY

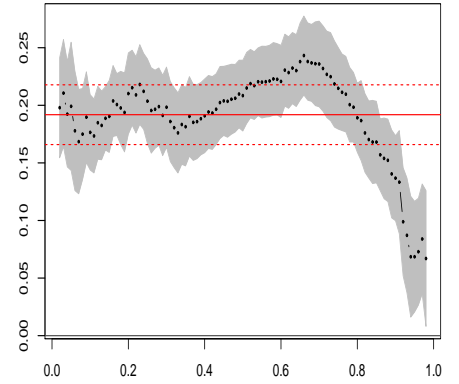

(g) COMM_RETAIL

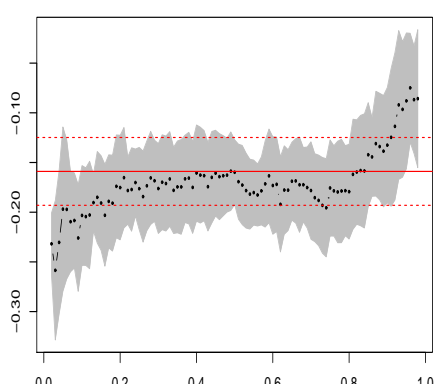

(d) TRUCKS

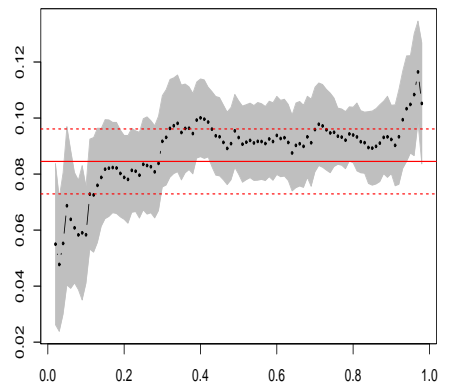

(h) TOURISM

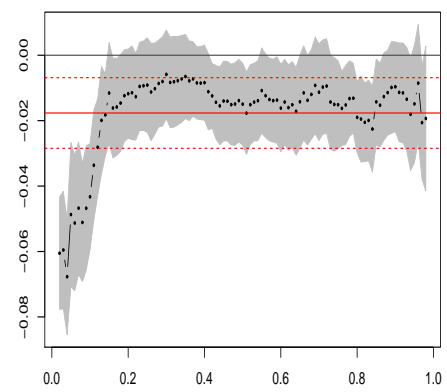

(i) DENSITY

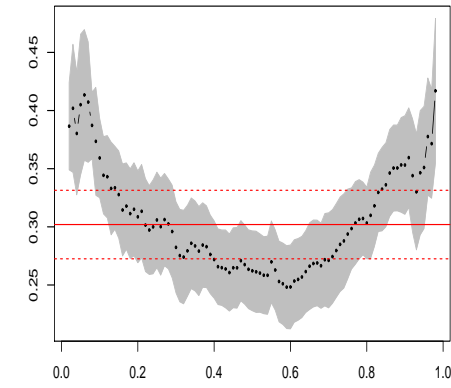

(j) $S A V I N G S_{2007}$

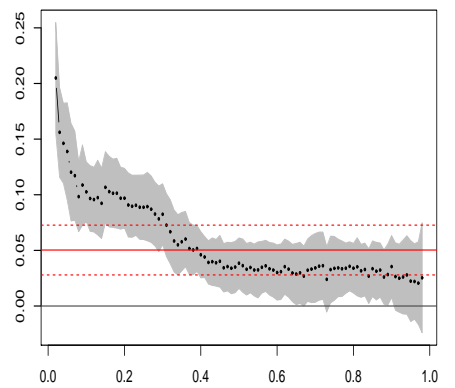

(k) UNIONS 2007

Notes: The dotted black line in each subfigure represents the point estimates, $\left\{\hat{\beta}_{j}(\tau): j=1, \ldots, 10\right\}$, with the shaded gray area depicting $90 \%$ pointwise confidence band. Superimposed on each plot is a red line representing the OLS estimate of the mean effect, with two dashed lines in red again representing a 90\% confidence interval for this coefficient. The solid line in black on each plot indicates the null effect $\left(\hat{\beta}_{j}=0\right)$ and, therefore, when the area in grey does not overlap with the $\hat{\beta}_{j}=0$ solid black line the coefficient is significant at the $10 \%$ level. 
Figure 6: Determinants of bank branch location, savings banks, regression quantiles, 2008

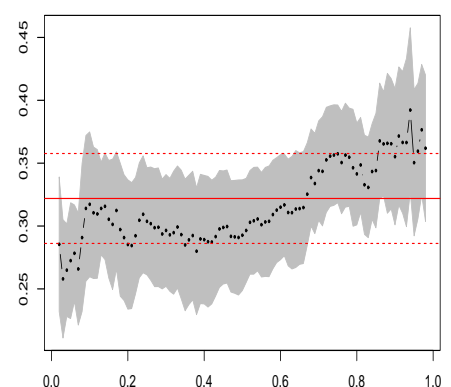

(a) POP_ESP

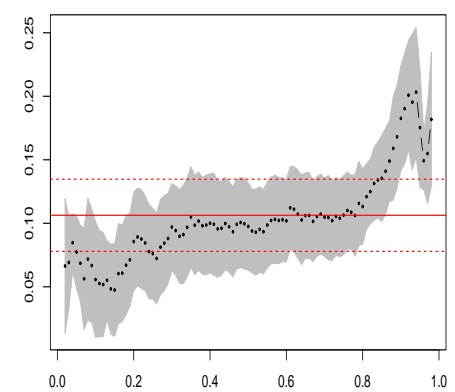

(e) IND_CONS

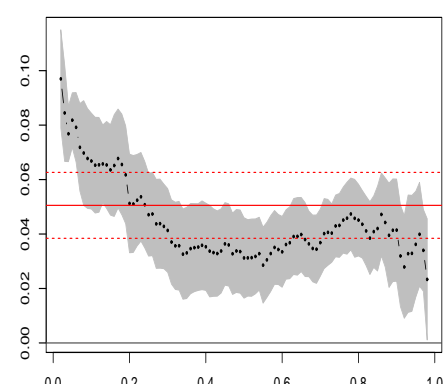

(b) POP_FOREIGN

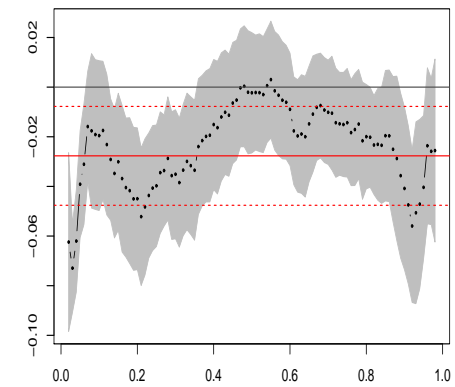

(f) COMM WHOLE

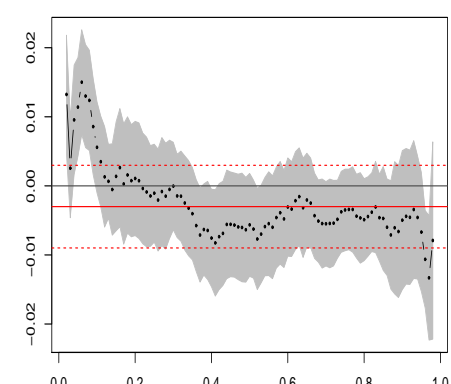

(c) UNEMPLOY

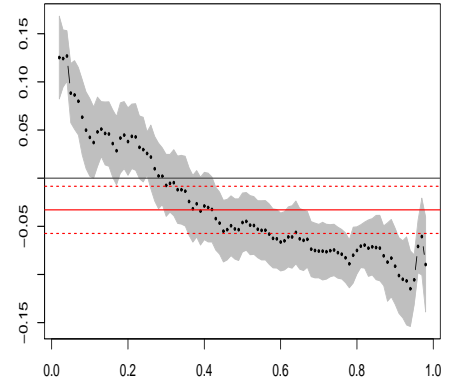

(g) COMM_RETAIL

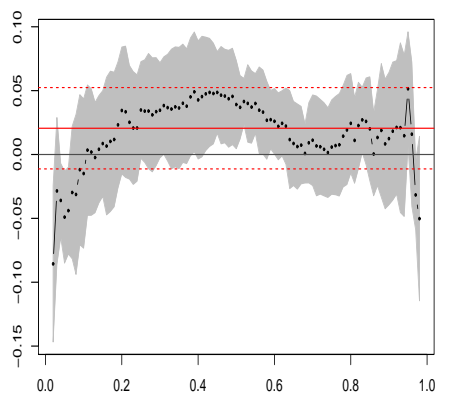

(d) TRUCKS

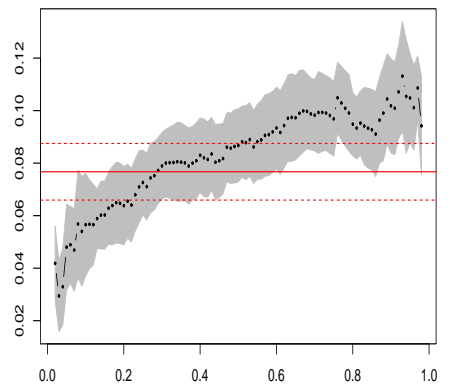

(h) TOURISM

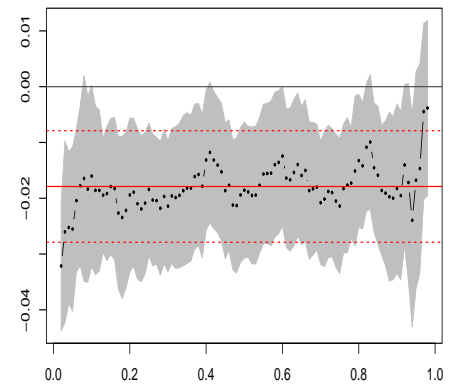

(i) DENSITY

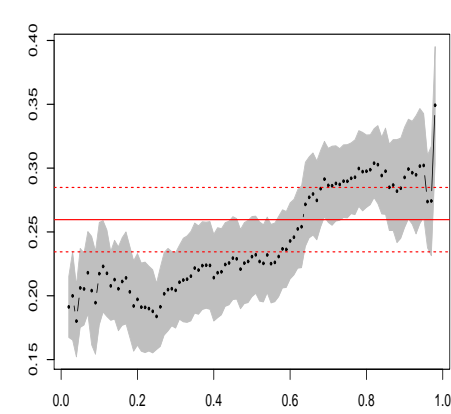

(j) $B A N K S_{2007}$

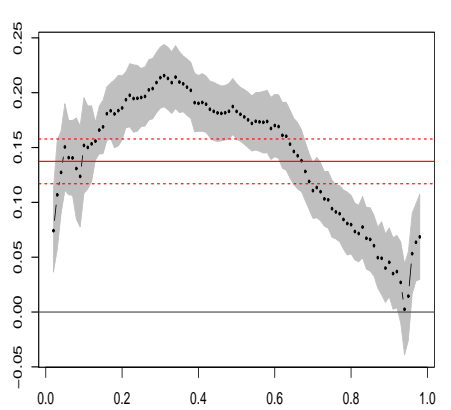

(k) UNIONS 2007

Notes: The dotted black line in each subfigure represents the point estimates, $\left\{\hat{\beta}_{j}(\tau): j=1, \ldots, 10\right\}$, with the shaded gray area depicting $90 \%$ pointwise confidence band. Superimposed on each plot is a red line representing the OLS estimate of the mean effect, with two dashed lines in red again representing a 90\% confidence interval for this coefficient. The solid line in black on each plot indicates the null effect $\left(\hat{\beta}_{j}=0\right)$ and, therefore, when the area in grey does not overlap with the $\hat{\beta}_{j}=0$ solid black line the coefficient is significant at the $10 \%$ level. 
Table 6: Determinants of bank branch location using quantile regression, all banking firms, 2008 (information at LAU level 2, formerly NUTS level 5)

\begin{tabular}{|l||c|c|c|c|c|c|c|}
\hline Covariates & $\tau=0.05$ & $\tau=0.10$ & $\tau=0.25$ & $\tau=0.50$ & $\tau=0.75$ & $\tau=0.90$ & $\tau=0.95$ \\
\hline (Intercept) & -3.614 & -3.097 & -2.544 & -2.589 & -2.712 & -2.271 & -2.253 \\
& $(0.220)$ & $(0.130)$ & $(0.102)$ & $(0.092)$ & $(0.115)$ & $(0.111)$ & $(0.118)$ \\
POP_ESP & 0.346 & 0.311 & 0.267 & 0.345 & 0.444 & 0.439 & 0.488 \\
\multirow{2}{*}{ POP_FOREIGN } & $(0.058)$ & $(0.030)$ & $(0.024)$ & $(0.020)$ & $(0.026)$ & $(0.026)$ & $(0.028)$ \\
& 0.139 & 0.110 & 0.071 & 0.062 & 0.030 & 0.045 & 0.050 \\
UNEMPLOY & $(0.022)$ & $(0.012)$ & $(0.009)$ & $(0.008)$ & $(0.009)$ & $(0.009)$ & $(0.011)$ \\
& -0.021 & -0.023 & -0.015 & -0.020 & -0.027 & -0.023 & -0.026 \\
TRUCKS & $(0.011)$ & $(0.005)$ & $(0.004)$ & $(0.004)$ & $(0.004)$ & $(0.003)$ & $(0.005)$ \\
& -0.050 & -0.053 & -0.027 & -0.010 & -0.018 & -0.044 & -0.100 \\
IND_CONS & $(0.055)$ & $(0.028)$ & $(0.020)$ & $(0.023)$ & $(0.022)$ & $(0.018)$ & $(0.021)$ \\
& 0.070 & 0.087 & 0.100 & 0.096 & 0.136 & 0.131 & 0.175 \\
COMM_WHOLE & $(0.049)$ & $(0.024)$ & $(0.020)$ & $(0.017)$ & $(0.020)$ & $(0.020)$ & $(0.027)$ \\
& -0.086 & -0.049 & 0.029 & 0.049 & 0.044 & 0.075 & 0.054 \\
COMM_RETAIL & $(0.035)$ & $(0.019)$ & $(0.013)$ & $(0.012)$ & $(0.015)$ & $(0.016)$ & $(0.018)$ \\
TOURISM & 0.394 & 0.371 & 0.297 & 0.202 & 0.107 & 0.049 & 0.035 \\
& $(0.044)$ & $(0.025)$ & $(0.018)$ & $(0.015)$ & $(0.018)$ & $(0.020)$ & $(0.024)$ \\
DENSITY & 0.023 & 0.028 & 0.044 & 0.076 & 0.125 & 0.162 & 0.155 \\
& $(0.014)$ & $(0.008)$ & $(0.007)$ & $(0.007)$ & $(0.009)$ & $(0.007)$ & $(0.008)$ \\
& -0.062 & -0.053 & -0.033 & -0.048 & -0.053 & -0.047 & -0.054 \\
& $(0.011)$ & $(0.008)$ & $(0.006)$ & $(0.005)$ & $(0.007)$ & $(0.006)$ & $(0.008)$ \\
\hline
\end{tabular}

Notes: the numbers represent coefficients for the estimated linear quantile regression for each of the selected quantiles $(\tau)$. Standard errors (in parentheses) are computed presuming local (in $\tau$ ) linearity (in $x$ ) of the conditional quantile functions and computes a Huber sandwich estimate using a local estimate of the sparsity. See Koenker (2010) for further details. 
Table 7: Determinants of bank branch location using quantile regression, commercial banks, 2008 (information at LAU level 2, formerly NUTS level 5)

\begin{tabular}{|l||c|c|c|c|c|c|c|}
\hline Covariates & $\tau=0.05$ & $\tau=0.10$ & $\tau=0.25$ & $\tau=0.50$ & $\tau=0.75$ & $\tau=0.90$ & $\tau=0.95$ \\
\hline (Intercept) & -1.631 & -1.991 & -1.949 & -1.842 & -1.445 & -1.229 & -1.233 \\
& $(0.243)$ & $(0.150)$ & $(0.155)$ & $(0.144)$ & $(0.152)$ & $(0.156)$ & $(0.216)$ \\
POP_ESP & 0.104 & 0.181 & 0.171 & 0.191 & 0.227 & 0.233 & 0.257 \\
& $(0.050)$ & $(0.035)$ & $(0.033)$ & $(0.029)$ & $(0.031)$ & $(0.029)$ & $(0.042)$ \\
POP_FOREIGN & 0.035 & 0.045 & 0.012 & 0.015 & -0.003 & -0.024 & -0.041 \\
& $(0.016)$ & $(0.010)$ & $(0.011)$ & $(0.010)$ & $(0.011)$ & $(0.012)$ & $(0.015)$ \\
UNEMPLOY & -0.013 & -0.020 & -0.022 & -0.026 & -0.027 & -0.018 & -0.020 \\
TRUCKS & $(0.008)$ & $(0.005)$ & $(0.005)$ & $(0.004)$ & $(0.006)$ & $(0.006)$ & $(0.005)$ \\
& -0.197 & -0.203 & -0.176 & -0.160 & -0.176 & -0.133 & -0.088 \\
IND_CONS & $(0.050)$ & $(0.030)$ & $(0.025)$ & $(0.020)$ & $(0.029)$ & $(0.035)$ & $(0.041)$ \\
& 0.147 & 0.165 & 0.191 & 0.178 & 0.104 & 0.113 & 0.139 \\
COMM_WHOLE & $(0.040)$ & $(0.027)$ & $(0.024)$ & $(0.022)$ & $(0.025)$ & $(0.027)$ & $(0.034)$ \\
COMM_RETAIL & 0.064 & 0.052 & 0.041 & 0.048 & 0.069 & 0.056 & 0.043 \\
TOURISM & $(0.029)$ & $(0.015)$ & $(0.018)$ & $(0.016)$ & $(0.016)$ & $(0.019)$ & $(0.025)$ \\
& 0.199 & 0.177 & 0.204 & 0.208 & 0.215 & 0.137 & 0.069 \\
DENSITY & $(0.034)$ & $(0.020)$ & $(0.022)$ & $(0.019)$ & $(0.021)$ & $(0.022)$ & $(0.029)$ \\
& 0.069 & 0.058 & 0.083 & 0.093 & 0.095 & 0.092 & 0.105 \\
SAVINGS 2007 & $(0.017)$ & $(0.011)$ & $(0.010)$ & $(0.008)$ & $(0.007)$ & $(0.007)$ & $(0.011)$ \\
& -0.049 & -0.043 & -0.009 & -0.015 & -0.015 & -0.010 & -0.015 \\
UNIONS 2007 & $(0.013)$ & $(0.010)$ & $(0.009)$ & $(0.008)$ & $(0.008)$ & $(0.008)$ & $(0.011)$ \\
& 0.405 & 0.359 & 0.306 & 0.262 & 0.294 & 0.353 & 0.351 \\
& $(0.037)$ & $(0.021)$ & $(0.025)$ & $(0.021)$ & $(0.023)$ & $(0.026)$ & $(0.032)$ \\
& 0.139 & 0.103 & 0.089 & 0.038 & 0.034 & 0.035 & 0.022 \\
& $(0.027)$ & $(0.016)$ & $(0.018)$ & $(0.014)$ & $(0.017)$ & $(0.017)$ & $(0.022)$ \\
\hline
\end{tabular}

Notes: the numbers represent coefficients for the estimated linear quantile regression for each of the selected quantiles $(\tau)$. Standard errors (in parentheses) are computed presuming local (in $\tau$ ) linearity (in $x$ ) of the conditional quantile functions and computes a Huber sandwich estimate using a local estimate of the sparsity. See Koenker (2010) for further details. 
Table 8: Determinants of bank branch location using quantile regression, savings banks, 2008 (information at LAU level 2, formerly NUTS level 5)

\begin{tabular}{|l||c|c|c|c|c|c|c|}
\hline Covariates & $\tau=0.05$ & $\tau=0.10$ & $\tau=0.25$ & $\tau=0.50$ & $\tau=0.75$ & $\tau=0.90$ & $\tau=0.95$ \\
\hline (Intercept) & -2.583 & -2.750 & -2.574 & -2.074 & -2.102 & -2.106 & -2.060 \\
& $(0.124)$ & $(0.156)$ & $(0.126)$ & $(0.128)$ & $(0.115)$ & $(0.154)$ & $(0.180)$ \\
POP_ESP & 0.272 & 0.317 & 0.304 & 0.293 & 0.357 & 0.355 & 0.350 \\
& $(0.028)$ & $(0.035)$ & $(0.026)$ & $(0.027)$ & $(0.024)$ & $(0.033)$ & $(0.035)$ \\
POP_FOREIGN & 0.082 & 0.067 & 0.047 & 0.031 & 0.043 & 0.041 & 0.036 \\
UNEMPLOY & $(0.006)$ & $(0.011)$ & $(0.009)$ & $(0.009)$ & $(0.007)$ & $(0.011)$ & $(0.012)$ \\
& 0.011 & 0.006 & -0.001 & -0.006 & -0.003 & -0.005 & -0.007 \\
TRUCKS & $(0.004)$ & $(0.004)$ & $(0.004)$ & $(0.005)$ & $(0.004)$ & $(0.006)$ & $(0.005)$ \\
& -0.049 & -0.015 & 0.035 & 0.039 & 0.006 & 0.012 & 0.051 \\
IND_CONS & $(0.022)$ & $(0.036)$ & $(0.023)$ & $(0.021)$ & $(0.022)$ & $(0.031)$ & $(0.027)$ \\
& 0.077 & 0.056 & 0.076 & 0.098 & 0.106 & 0.183 & 0.175 \\
COMM_WHOLE & $(0.017)$ & $(0.028)$ & $(0.022)$ & $(0.021)$ & $(0.019)$ & $(0.025)$ & $(0.029)$ \\
COMM_RETAIL & -0.039 & -0.020 & -0.040 & -0.002 & -0.014 & -0.041 & -0.040 \\
TOURISM & $(0.013)$ & $(0.018)$ & $(0.015)$ & $(0.015)$ & $(0.013)$ & $(0.020)$ & $(0.018)$ \\
DENSITY & 0.088 & 0.042 & 0.026 & -0.046 & -0.077 & -0.091 & -0.106 \\
& $(0.019)$ & $(0.024)$ & $(0.014)$ & $(0.019)$ & $(0.016)$ & $(0.024)$ & $(0.016)$ \\
BANKS 2007 & 0.048 & 0.057 & 0.073 & 0.087 & 0.097 & 0.102 & 0.105 \\
& $(0.010)$ & $(0.012)$ & $(0.007)$ & $(0.008)$ & $(0.009)$ & $(0.011)$ & $(0.010)$ \\
UNIONS 2007 & -0.026 & -0.016 & -0.018 & -0.019 & -0.021 & -0.018 & -0.017 \\
& $(0.009)$ & $(0.010)$ & $(0.007)$ & $(0.007)$ & $(0.007)$ & $(0.009)$ & $(0.012)$ \\
& 0.206 & 0.217 & 0.184 & 0.231 & 0.290 & 0.293 & 0.302 \\
& $(0.019)$ & $(0.024)$ & $(0.016)$ & $(0.019)$ & $(0.017)$ & $(0.024)$ & $(0.025)$ \\
& 0.151 & 0.152 & 0.196 & 0.183 & 0.094 & 0.045 & 0.015 \\
& $(0.024)$ & $(0.026)$ & $(0.016)$ & $(0.015)$ & $(0.016)$ & $(0.019)$ & $(0.024)$ \\
\hline
\end{tabular}

Notes: the numbers represent coefficients for the estimated linear quantile regression for each of the selected quantiles $(\tau)$. Standard errors (in parentheses) are computed presuming local (in $\tau$ ) linearity (in $x$ ) of the conditional quantile functions and computes a Huber sandwich estimate using a local estimate of the sparsity. See Koenker (2010) for further details. 
Table 9: ANOVA for testing the equality of the slope coefficients for different quantiles $(\tau)$

\begin{tabular}{|c|c|c|c|}
\hline & All banking firms & Commercial banks & Savings banks \\
\hline$F$ & 9.5974 & 5.0740 & 5.9003 \\
\hline$p$-value & 0.0000 & 0.0000 & 0.0000 \\
\hline
\end{tabular}

Notes: the null hypothesis being tested is whether the slope coefficients for the different values of $\tau$ are equal, for each type of banking aggregate (all banking firms, commercial banks, or savings banks). Formally:

$$
H_{0}: \beta_{\tau=.05}=\beta_{\tau=.10}=\ldots=\beta_{\tau=.90}=\beta_{\tau=.95}
$$

See Koenker (2010) for further details. 
The plots in Figures 4-6 offer a much richer and focused view than the one we obtain by looking exclusively at conditional mean models (Koenker, 2005, p.25). For instance, as revealed by Figure $4 \mathrm{~b}$, the effect of foreign-born immigrants on service accessibility measured as the number of bank offices in each municipality is 0.075 , as indicated both in Table 5, Model 1 , and the red solid line in Figure $4 \mathrm{~b}$. This is the average effect. The dotted black line in Figure $4 \mathrm{~b}$ is far more informative, revealing that the effect is three times larger for the lower tail of the distribution, i.e., for municipalities with few bank offices. This result also adds to the reported evidence on the financial exclusion of foreign-born communities.

The individual analyses for commercial banks (Figure 5b) and savings banks (Figure 6b) clearly indicate that the banking firms contributing to financial inclusion are savings banks. Both Figure $5 \mathrm{~b}$ and Table 7 show that the effect of this covariate on the number of offices is only significant for the lowest quantile $(\tau=0.05)$. In contrast, the effect on the number of savings banks' branches is positive and significant for all the quantiles considered, as revealed by Table 8 and Figure $6 \mathrm{~b}$. As opposed to this findings considering the different types of firms separately, the pattern for natives (Figures $4 a, 5 a$ and $6 a$ ) is more stable across the conditional distribution.

The quantile regression results for the economic performance variables (UNEMPLOY) also report some interesting findings compared to the OLS results. For instance, in the case of commercial banks, the effect of unemployment (Figure $5 c$ and Table 6 ) indicates that the negative and significant average impact yielded by OLS is corroborated for different quantiles of the distribution, but, in the case of savings banks (Figure $6 c$ and Table 8), the effect is either non-significant or, for the lower tail of the distribution, positive. This result was not revealed by Table 5 suggesting, once more, that savings banks are contributing to financial inclusion and service accessibility for low-income communities much more decidedly than commercial banks.

The economic activity variables (TRUCKS, IND_CONS, COMM_WHOLE, COMM_RETAIL and TOURISM) clearly indicate that, for all banking firms, as shown in Figures $4 \mathrm{~d}-4 \mathrm{~h}$, and Table 6, OLS results miss relevant trends since, with perhaps the exception of IND_CONS, the rest of the variables show a very different effect for the upper and lower tails of the distribution.

For instance, TRUCKS was not significant for the conditional-mean model (OLS), as revealed by Model 1 in Table 5. However, both Table 6 and Figure 4d reveal this result does not hold for the highest quantiles ( $\tau=0.90$ and $\tau=0.95$ ), a result invisible for OLS. As suggested 
earlier, this could be related to the fact that some banking firms have a lack of presence in rural areas, where this type of vehicles abound (this category also includes vans and tractors, as suggested before). The behavior is very different for commercial banks and savings banks. For the former, the impact is negative and significant for all quantiles (Table 7 and Figure 5d), whereas the impact is either not significant or even positive (and significant) for the highest quantiles (Table 8 and Figure 6d) in the case of savings banks.

The rest of the economic variables (IND_CONS,COMM_WHOLE,COMM_RETAIL and TOURISM) have expected signs for banks (they are positive and significant throughout the conditional distribution, as revealed by Table 6 and Figures 5e, 5f, 5g and 5h). However, this result is not entirely mimicked for savings banks, for which the commercial activity variables have a negative and significant effect for some quantiles (see Table 8 and Figures $6 \mathrm{f}-6 \mathrm{~g}$ ). Again, this might be related to the fact that savings banks do not take into account only economic considerations when designing expansion policies but also would be pursuing objectives aimed at helping to reduce financial exclusion (p.107 Carbó et al., 2005).

These results are not as sharp when the analysis is performed for commercial banks and savings banks separately. In the case of the environmental variable considered (DENSITY) there is an opposite pattern, as in this case a specific analysis for commercial banks (Table 7 and Figure 5i) indicates that the (negative) effect is much larger for under-branched areas, pointing out the relatively absence of commercial banks' offices in rural areas.

Finally, the quantile regression analysis for the financial variables also reveals some interesting trends which OLS regressions could not uncover. Recall that the corresponding regressors are lagged (they correspond to year 2007 information). In the case of savings banks, Table 8 and Figure $6 j$ corroborate that the rival precedence behavior of these type of firms is a reality. The new result uncovered by quantile regression is that the presence of savings bank branches is especially remarkable in locations where the number of commercial bank branches is higher; in contrast, as revealed by Table 8 and Figure $6 \mathrm{k}$, in locations where there are more savings bank branches, the presence of credit union branches is comparatively low, suggesting a complementary role of savings banks and credit unions.

\section{Conclusions}

This paper has explored the determinants of bank branch location in Spain, with a special focus on their implications for financial exclusion. The issue is important for a number of 
reasons. While the reduction in branch numbers has been a dominant trend in many countries over the last few years, in Spain, after the passing of the 1989 law which allowed savings banks to branch freely across the entire country, the total number of bank branches increased by $50 \%$, and the number of savings bank branches increased in greater proportions, doubling between 1988 (the year prior to deregulation) and 2008, a similar trend to that taking place for credit unions. However, with the upsurge of the economic and financial crisis which is affecting many countries, the trend has reversed over the last two years. Savings banks and credit unions have been closing branches, and this trend will probably intensify due to the restructuring affecting savings banks.

These trends may be important for several reasons, one of the most significant being that they might affect the availability of financial services in some communities. This issue has been analyzed intensely by the literature on financial exclusion. Our analysis has attempted to explore it from different perspectives to those considered until now. With respect to some previous studies focusing in the Spanish banking industry (notably Bernad et al., 2008), we choose a broader perspective by enlarging the set of covariates, providing a separate analysis for commercial banks, savings banks, and credit cooperatives, and performing the analysis for a recent and relevant year (2008). The scant previous literature, especially in the European context, considered arguments that considered less restrictive banking would result into improved service accessibility. Yet, as indicated by Evanoff (1988), the links between bank branching and service accessibility have been ultimately an empirical question.

For undertaking the analysis, we adopt a point of view which considers that the variables affecting the number of branches in each municipality have not necessarily to remain constant along the conditional distribution of the dependent variable. In other words, we consider that it might be simplistic to postulate an average effect for the average municipality. In contrast, we advocate for a more flexible method, such as quantile regression (Koenker and Bassett, 1978; Koenker, 2001), which enables the researcher to consider the entire distribution of location patterns, whereas OLS considers only the distribution mean.

Our results can be explored from a multiplicity of angles. They corroborate previous evidence, suggesting the main determinants of bank branch location are related to population and income variables. We extend this general result in some ways. Firstly, we have added several covariates to the model, and also split some of the variables already analyzed, which enriched the available interpretations. Our flexible techniques, which stipulate that the effect of a given variable can be too intricate to be summarized in an average effect for the average 
municipality, added further insights to the results, since the effect of several variables was different according to the tail of the distribution being examined.

In addition, when the analysis was split between the different types of financial institutions (commercial banks, savings banks and credit unions) results were particularly enriched. One of the most interesting achievements is related to the fact that, although the three types of institutions are allowed to perform the same operations, substantial differences remain in some particular areas, one of which affects bank branch location, service accessibility and, therefore, their relative contributions to financial inclusion. Although one of the consequences of the recent international financial and economic crisis in Spain has been the re-structuring of the savings bank sector, with most of them now immerse in far-reaching merger processes, our results indicate that this type of institution has greatly contributed to financial inclusion in Spain. The merger processes may be jeopardizing this notable role, as they will ultimately result in a much lower number of savings banks, whose regional links will be weaker. Therefore, although the costs of not adopting the model proposed by Jack Revell (1989) might have been high, restructuring the sector ignoring the financial inclusion role played by savings banks could also bring important costs. 


\section{References}

Barro, R. and Sala-i-Martin, X. (1992). Regional growth and migration: A Japan-United States comparison. Journal of the Japanese and International Economies, 6(4):312-346.

Basile, R. and Girardi, A. (2010). Specialization and risk sharing in European regions. Journal of Economic Geography, 10(5):645-659.

Bassett, G. and Koenker, R. (1978). Asymptotical theory of least absolute value error regression. Journal of the American Statistical Association, 73:618-622.

Bernad, C., Fuentelsaz, L., and Gómez, J. (2008). Deregulation and its long-run effects on the availability of banking services in low-income communities. Environment and Planning A, 40(7):1681-1696.

Bierman, L., Fraser, D. R., Gimeno, J., and Fuentelsaz, L. (1995). Regulatory change and the availability of banking facilities in low-income areas: a Texas empirical study. SMU Law Review, 49:1421-1446.

Bresnahan, T. F., Reiss, P. C., Willig, R., and Stigler, G. J. (1987). Do entry conditions vary across markets? Brookings Papers on Economic Activity, 1987(3):833-881.

Buchinsky, M. (1998). Recent advances in quantile regression models: a practical guideline for empirical research. Journal of Human Resources, 33(1):88-126.

Cade, B. S. and Noon, B. R. (2003). A gentle introduction to quantile regression for ecologists. Frontiers in Ecology and the Environment, 1(8):412-420.

Calem, P. S. and Nakamura, L. I. (1988). Branch banking and the geography of bank pricing. Review of Economics and Statistics, 80:600-610

Carbó, S., Gardener, E., and Molyneux, P. (2007). Financial exclusion in Europe. Public Money \& Management, 27(1):21-27.

Carbó-Valverde, S. and Rodríguez-Fernández, R. (2004). The Finance-Growth Nexus. European Urban and Regional Studies, 11(4):339.

Carbó, S., Gardener, E., and Molyneux, P. (2005). Financial Exclusion. Palgrave MacMillan.

Carbó, S., Humphrey, D. B., and Rodríguez-Fernández, F. (2003). Deregulation, bank competition and regional growth. Regional Studies.

Carbó-Valverde, S., López del Paso, R., and Rodríguez-Fernández, F. (2007). Financial innovations in banking: impact on regional growth. Regional Studies, 41(3):311-326.

Casetti, E. (1972). Generating models by the expansion method: applications to geographical research. Geographical Analysis, 4(1):81-91.

Casetti, E. (1991). The investigation of parameter drift by expanded regressions: generalities, and a 'family planning' example. Environment and Planning A, 23(7):1045-1061.

Chang, A., Chaudhuri, S., and Jayaratne, J. (1997). Rational herding and the spatial clustering of bank branches: an empirical analysis. Research Paper 9724, Federal Reserve Bank of New York, New York, NY.

Coad, A. and Hölzl, W. (2009). On the autocorrelation of growth rates. Journal of Industry, Competition and Trade, 9(2):139-166.

Crawford, R. J. (1973). A comparison of the internal urban spatial pattern of unit and branch bank offices. The Professional Geographer, 25(4):353-356. 
Cunningham, B. M. (2003). The distributional heterogeneity of growth effects: some evidence. The Manchester School, 71(4):417447.

Damar, H. E. (2007). Does post-crisis restructuring decrease the availability of banking services? The case of Turkey. Journal of Banking \& Finance, 31(9):2886-2905.

De Juan, R. (2003). The independent submarkets model: an application to the Spanish retail banking market. International Journal of Industrial Organization, 21:1461-1487.

De Juan, R. (2008). Competition in local markets: Some evidence from the Spanish retail banking market. Review of Industrial Organization, 32(2):145-162.

Demirgüç-Kunt, A. (2010). Finance and economic development: The role of government. In Berger, A. N., Molyneux, P., and Wilson, J. O. S., editors, The Oxford Handbook of Banking, chapter 29, pages 729-755. Oxford University Press, New York.

Demirgüç-Kunt, A. and Servén, L. (2010). Are all the sacred cows dead? Implications of the financial crisis for macro-and financial policies. The World Bank Research Observer, forthcoming.

Eldridge, J. D. and Jones, J. P. (1991). Warped space: A geography of distance decay. The Professional Geographer, 43(4):500-511.

Evanoff, D. D. (1988). Branch banking and service accessibility. Journal of Money, Credit and Banking, 20(2):191-202.

Foster, S. A. (1991). The expansion method: implications for geographic research. The Professional Geographer, 43(2):131-142.

Fotheringham, A. S., Brunsdon, C., and Charlton, M. (2002). Geographically Weighted Regression: The Analysis of Spatially Varying Relationships. John Wiley \& Sons Inc, Chichester.

Freeman, D. G. (2002). Did state bank branching deregulation produce large growth effects? Economics Letters, 75(3):383-389.

Fuentelsaz, L. and Gómez, J. (1998). Liberalización y ámbito geográfico de actuación: Un análisis para las cajas de ahorros. Papeles de Economía Española, 74-75:190-201.

Fuentelsaz, L. and Gómez, J. (2001). Strategic and queue effects on entry in Spanish banking. Journal of Economics and Management Strategy, 10(4):529-563.

Fuentelsaz, L. and Gómez, J. (2006). Multipoint competition, strategic similarity and entry into geographic markets. Strategic Management Journal, 27:477-499.

Fuentelsaz, L., Gómez, J., and Polo, Y. (2002). Followers' entry timing: Evidence from the Spanish banking sector after deregulation. Strategic Management Journal, 23(3):245-264.

Gilbert, G. G. (1974). Predicting de novo expansion in bank merger cases. Journal of Finance, 29(1):151-162.

Gunther, J. W. (1997). Geographic liberalization and the accessibility of banking services in rural areas. Technical report, Federal Reserve Bank of Dallas, Dallas, TX.

Hannan, T. H. and McDowell, J. M. (1987). Rival precedence and the dynamics of technology adoption: an empirical analysis. Economica, 54:155-171.

Hao, L. and Naiman, D. Q. (2007). Quantile Regression. Number 149 in Quantitative Applications in the Social Sciences. Sage Publications, Thousand Oaks, CA.

Hierro, M. and Maza, A. (2009). Per capita income convergence and internal migration in Spain: Are foreign-born migrants playing an important role? Papers in Regional Science, 89(1):89-107. 
Hierro, M. and Maza, A. (2010). Foreign-born internal migrants: Are they playing a different role than natives on income convergence in Spain? Applied Geography, 30:618-628.

Illueca, M., Pastor, J. M., and Tortosa-Ausina, E. (2009). The effects of geographic expansion on the productivity of Spanish savings banks. Journal of Productivity Analysis, 32(2):119-143.

Jayaratne, J. and Strahan, P. E. (1996). The finance-growth nexus: Evidence from bank branch deregulation. The Quarterly Journal of Economics, 111(3):639-670.

Joassart-Marcelli, P. and Stephens, P. (2010). Immigrant banking and financial exclusion in Greater Boston. Journal of Economic Geography, 10(6):883-912.

Jones, J. P. (1992). Paradigmatic dimensions of the expansion method. In Jones, J. P. and Casetti, E., editors, Applications of the Expansion Method, pages 32-46. Routledge, London.

Jones, K. and Bullen, N. (1994). Contextual models of urban house prices: a comparison of fixed-and random-coefficient models developed by expansion. Economic Geography, 70(3):252-272.

Kochanowski, P. (1990). The expansion method as a tool of regional analysis. Regional Science Perspectives, 20(2):52-66.

Koenker, R. (2001). Quantile regression. Journal of Economic Perspectives, 15(4):143-156.

Koenker, R. (2005). Quantile Regression. Cambridge University Press.

Koenker, R. (2010). quantreg: Quantile Regression. R package version 4.53.

Koenker, R. and Bassett, G. (1978). Regression quantiles. Econometrica, 46(1):33-50.

Krol, R. and Svorny, S. (1996). The effect of the bank regulatory environment on state economic activity. Regional Science and Urban Economics, 26(5):531-541.

Kroszner, R. S. and Strahan, P. E. (1999). What drives deregulation? Economics and politics of the relaxation of bank branch restrictions. Quarterly Journal of Economics, 114(4):1437-1467.

Lanzillotti, R. F. and Saving, T. R. (1969). State branching restrictions and the availability of branching services: Comment. Journal of Money, Credit and Banking, 1(4):778-788.

Leyshon, A. and Thrift, N. (1995). Geographies of financial exclusion: financial abandonment in Britain and the United States. Transactions of the Institute of British Geographers, New Series, 20:312-341.

Leyshon, A. and Thrift, N. (1996). Financial exclusion and the shifting boundaries of the financial system. Environment and Planning A, 28(7):1150-1156.

Marshall, J. N. (2004). Financial institutions in disadvantaged areas: a comparative analysis of policies encouraging financial inclusion in Britain and the United States. Environment and Planning A, 36(2):241-261.

Okeahalam, C. (2009). Bank branch location: a count analysis. Spatial Economic Analysis, 4(3):275-300.

Østbye, S. and Westerlund, O. (2007). Is migration important for regional convergence? Comparative evidence for Norwegian and Swedish counties, 1980-2000. Regional Studies, 41(7):901-915.

Pollard, J. S. (1996). Banking at the margins: a geography of financial exclusion in Los Angeles. Environment and Planning A, 28:1209-1232. 
Quah, D. T. (1996). Twin Peaks: Growth and convergence in models of distribution dynamics. Economic Journal, 106(437):10451055.

Revell, J. (1989). The future of savings banks: A study of Spain and the rest of Europe. Research Monographs in Banking and Finance 8, Institute of European Finance, Bangor, UK.

Rioja, F. and Valev, N. (2004a). Does one size fit all?: a reexamination of the finance and growth relationship. Journal of Development Economics, 74(2):429-447.

Rioja, F. and Valev, N. (2004b). Finance and the sources of growth at various stages of economic development. Economic Inquiry, 42(1):127-140.

Savage, D. T. and Humphrey, D. B. (1979). Branching laws and banking offices: Comment. Journal of Money, Credit and Banking, 11(2):227-230.

Seaver, W. L. and Fraser, D. R. (1979). Branch banking and the availability of banking services in metropolitan areas. Journal of Financial and Quantitative Analysis, 14(1):153-160.

Shioji, E. (2001). Composition effect of migration and regional growth in Japan. Journal of the Japanese and International Economies, 15(1):29-49.

Sinclair, S. P. (2001). Financial Exclusion: An Introductory Survey. CRSIS/Heriot-Watt University, Edinburgh.

Sutton, J. (1997). One smart agent. Rand Journal of Economics, 28(4):605-628. 


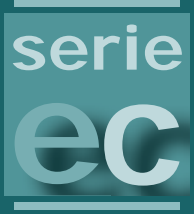

\section{I vie}

Guardia Civil, 22 - Esc. 2, 1음

46020 Valencia - Spain

Phone: +34 963190050

Fax: +34 963190055

Website: http:/ / www.ivie.es

E-mail: publicaciones@ivie.es 